\title{
Child Labour, Education and Export Performance
}

\author{
Working Paper No. 52
}

\section{David Kucera and Ritash Sarna}

\author{
Statistical Development and Analysis Unit \\ Policy Integration Department \\ International Labour Office \\ Geneva
}

December 2004 
Copyright (C) International Labour Organization 2005

Publications of the International Labour Office enjoy copyright under Protocol 2 of the Universal Copyright Convention. Nevertheless, short excerpts from them may be reproduced without authorization, on condition that the source is indicated. For rights of reproduction or translation, application should be made to the Publications Bureau (Rights and Permissions), International Labour Office, CH-1211 Geneva 22, Switzerland. The International Labour Office welcomes such applications.

Libraries, institutions and other users registered in the United Kingdom with the Copyright Licensing Agency, 90 Tottenham Court Road, London W1T 4LP [Fax: (+44) (0)20 7631 5500; email: cla@cla.co.uk], in the United States with the Copyright Clearance Center, 222 Rosewood Drive, Danvers, MA 01923 [Fax: (+1) (978) 750 4470; email: info@copyright.com] or in other countries with associated Reproduction Rights Organizations, may make photocopies in accordance with the licences issued to them for this purpose.

ISBN 92-2-116906-5 (printed version)

ISBN 92-2-116907-3 (Web version)

First published 2005

Cover:

The designations employed in ILO publications, which are in conformity with United Nations practice, and the presentation of material therein do not imply the expression of any opinion whatsoever on the part of the International Labour Office concerning the legal status of any country, area or territory or of its authorities, or concerning the delimitation of its frontiers.

The responsibility for opinions expressed in signed articles, studies and other contributions rests solely with their authors, and publication does not constitute an endorsement by the International Labour Office of the opinions expressed in them.

Reference to names of firms and commercial products and processes does not imply their endorsement by the International Labour Office, and any failure to mention a particular firm, commercial product or process is not a sign of disapproval.

ILO publications can be obtained through major booksellers or ILO local offices in many countries, or direct from ILO Publications, International Labour Office, CH-1211 Geneva 22, Switzerland. Catalogues or lists of new publications are available free of charge from the above address, or by email: pubvente@ilo.org

Visit our website: www.ilo.org/publns 


\section{Child Labour, Education and Export Performance}

\section{Contents}

Abstract

Preface

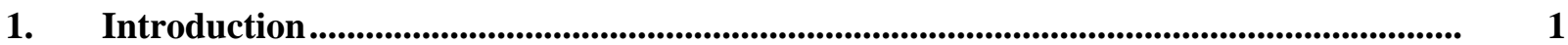

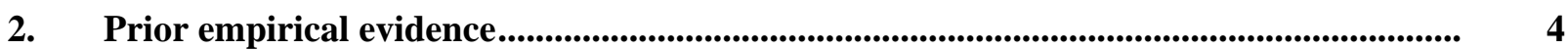

Rodrik (1996)............................................................................................................ 5

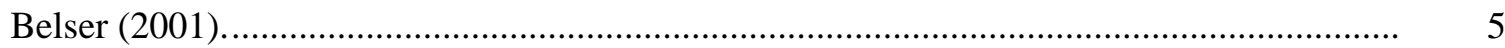

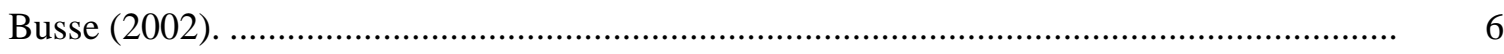

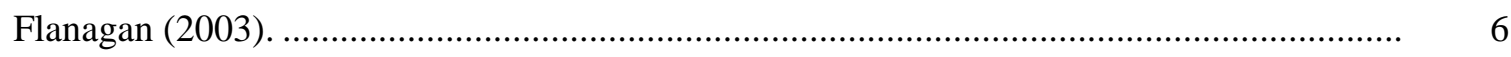

3. Indicators of child labour and education ............................................................................. 7

4. The trade model and industry classifications by labour and skill intensity......................... 8

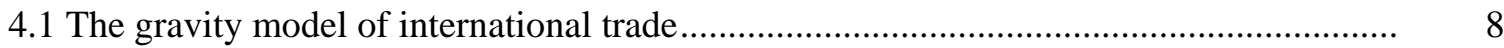

4.2 Industry classifications by labour and skill intensity and benchmark model results ........ 11

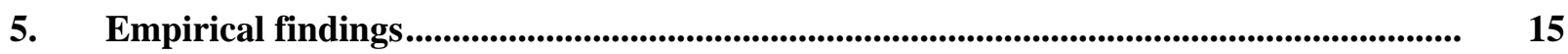

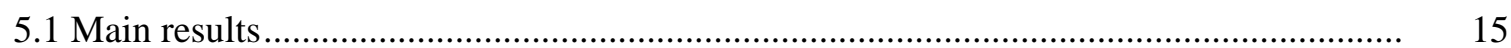

5.2 Sensitivity analysis and regional variation.................................................................... 18

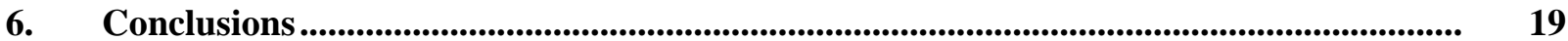

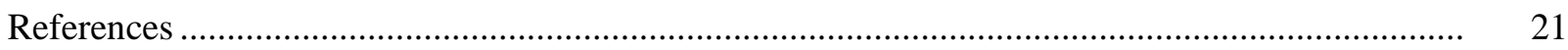

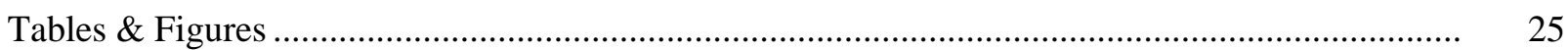

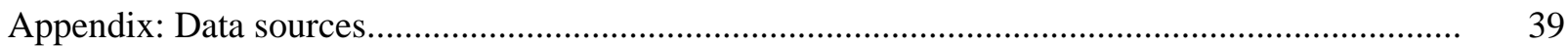

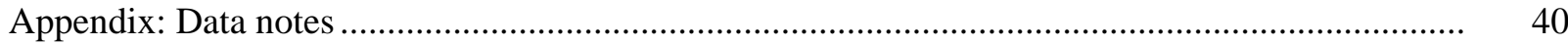




\section{Abstract}

The paper uses a gravity trade model to estimate the effects of child labour and education on exports for the 1993 to 1999 period, evaluating total exports, total manufacturing exports and manufacturing exports broken down by labour and skill intensity of production using four different classifications of industries. The model includes data for up to 162 countries, double that of prior studies, and employs several indicators of child labour (the economic activity rate of ten to fourteen year olds and secondary education non-enrollment rates) and education (average years of educational attainment and literacy rates). This paper provides robust statistical evidence that child labour is bad and education is good for exports, including for unskilled labour-intensive manufacturing exports for which results are generally similar to total manufacturing exports. These findings hold for both full samples of developed and developing countries and for samples including only developing countries as exporters. 


\section{Preface}

A longstanding economic policy debate of crucial importance for the ILO is whether countries with higher labour standards are at a disadvantage with respect to international trade competitiveness, particularly for trade of labour-intensive goods. As old as this debate is, it has intensified in recent years alongside the expansion of trade in competing goods between countries having widely varying labour standards and also widely varying labour costs. This debate, though receiving much attention in both academic and policy circles, has unfolded amidst considerably less empirical evidence than one would hope for.

Moreover, the debate has tended to focus on a fairly narrow range of causal channels between labour standards and trade competitiveness. With respect to child labour, for instance, the debate has focused on the effect of child labour through the relative supply of unskilled labour thus, it is argued, affecting a country's comparative trade advantage for unskilled labour-intensive goods. Kucera and Sarna's paper refers to this as "the HecksherOhlin causal channel with respect to relative endowments of unskilled labour." Based on the work of Adrian Wood, the paper argues that this causal channel is suspect in that there are, in developing countries, two rather separate markets for unskilled labour, and children work in the less skilled of these which is of limited relevance for the trade of manufactures. Kucera and Sarna argue for the greater plausibility of the education causal channel, based in particular on a key point of convergence of otherwise contrary accounts of East Asian growth: that education was of critical importance in contributing to the growth of manufacturing exports and to economic growth and development more generally. And over the course of economic development, the authors argue that child labour and education are by and large opposite sides of the same coin.

The authors undertake an econometric analysis of the effects of child labour and education on exports, including total exports and manufacturing exports broken down by labourintensity and skill-intensity of production. Their findings are consistent with the education causal channel and show that countries with less child labour and higher educational attainment tend to have higher exports, including exports of unskilled labour-intensive manufactures. The authors' findings are based on data for 162 countries, double that of prior studies, and are derived from the gravity trade model, which has a solid record of yielding statistically robust empirical results. 


\section{Introduction}

There is a point on which otherwise contrary accounts of East Asian development agree: the crucial importance of education in facilitating the growth of manufacturing exports and economic growth more generally. The World Bank in its influential report The East Asian Miracle argues against the importance of industrial policy. Rather the World Bank writes:

In large measure the HPAEs [high performing Asian economies] achieved high growth by getting the basics right. Private domestic investment and rapidly growing human capital were the principal engines of growth.... And some of these economies also got a head start because they had a better-educated labor force... (World Bank 1993, p. 5).

Such advocates of industrial policy as Amsden also emphasize the importance of education, arguing that it was of particular importance for late-industrializers whose developmental success depended on their ability to "absorb foreign know-how" (Amsden 2001, p. 63; cf. Wade 2004, p. xvii). Summarizing their view of the key determinants of this success, Di Caprio and Amsden write:

The latecomers were able to industrialize rapidly as a result of two key historical factors. The first was pre-war manufacturing experience. This gave the countries an understanding of technology and a degree of industrial infrastructure. The other factor was that their populations were relatively well educated. This is important because technology transfer is inefficient without absorption capacity in the receiving country (Di Caprio and Amsden 2004, p. 2).

The World Bank report states "In nearly all the rapidly growing East Asian economies, the growth and transformation of systems of education and training during the past three decades has been dramatic" (ibid., p. 43). A sense of this transformation is provided by figure 1, which shows average years of educational attainment from 1960 to 1999 for the set of economies the World Bank defines as high performing Asian economies. Particularly dramatic are the increases for the the Republic of Korea and Taiwan (China).

It is argued by Wood and Berge that the manufacturing export success of East Asia reflects the realization of latent comparative advantage in manufactured goods based on relative factor endowments, particularly relative endowments of skilled labour. The authors write, "Changes in trade policy during the past three decades enabled many developing countries, notably in East Asia, to realise a previously stifled comparative advantage in manufacturing" (Wood and Berge 1997, p. 54). Wood and Berge's argument is based on their finding of a strong positive cross-country relationship between two ratios: the ratio of manufacturing to primary goods exports and the ratio skill per worker to land per worker, with skill per worker measured by the average years of educational attainment. ${ }^{1}$ What is clear from figure 1 , though, is that if it is indeed meaningful to consider education - like land - as an endowment, then it is an endowment of a highly malleable sort, one that can change with comparative rapidity in response to government policies.

\footnotetext{
${ }^{1}$ In their critique of industrial policy, a similar view of education as an endowment is provided by Noland and Pack, who write of the "unusually high level of education in Korea and Taiwan at the beginning of the industrialization effort” (Noland and Pack 2003, p. 22). The authors go on to write that "The increasing education levels were not the result of industrial policy:... Japanese and Korean human capital in the mid-1950s was already high relative to their per capita income” (ibid., p. 98).
} 
Regarding its effect on exports, it is useful to view education in an absolute rather than relative sense - as providing a critical threshold ability for countries to profitably produce for world markets at world prices - but also in a dynamic sense. ${ }^{2}$ Consistent with this dynamic view are the findings of Levin and Raut in their cross-country analysis of semi-industrialized countries regarding the determinants of their economic growth (Levin and Raut 1997). The authors write that their results "indicate a high degree of complementarity between trade policies and education expenditures" as regards manufacturing exports, which they argue provides "further support for development policies that stimulate long-run economic growth by simultaneously promoting investment in human capital as well as investment in the manufacturing export sector” (ibid., p. 157-58).

Studies of the economics of child labour commonly refer to the relationship between child labour and education (e.g., Basu 1999; Busse 2002; Galli 2001; Gormly and Swinnerton 2004; IPEC 2003; Sherburne 2001). For example, Basu writes that "the dynamic consequences of child labor are likely to be large, since an increase in child labor frequently causes a decline in the acquisition of human capital” (ibid., 1106). It is an overstatement to regard education as the simple inverse of child labour, for children can and do combine work with school attendance, depending critically on the number and seasonality of hours worked (cf. Basu 1999, p. 1093 for a summary of relevant case studies). And of course a decline in child labour will only lead to an increase in educational attainment in the presence of schools that are both accessible and affordable and also of sufficient quality that parents regard them as useful. But it is not happenstance that the increase in educational attainment in East Asia occurred alongside rapid declines in the economic activity rates of ten to fourteen year olds and indeed that the declines in East Asia were more rapid than for any other region in the world (ILO 1996). ${ }^{3}$ More than that, there are (we will see) strong negative cross-country correlations between measures of child labour and education. This evidence suggests that through the course of economic development, education and child labour are by and large opposite sides of the same coin. ${ }^{4}$

The effect of an increase in child labour on trade is commonly viewed as operating through an increase in the supply of unskilled labour, increasing the relative endowment of unskilled labour and thus shifting a country's comparative advantage more toward labour-intensive goods produced by unskilled workers (Busse 2002; Rodrik 1996; Sherburne 2001). The effect of a decline in child labour is commonly viewed to work just oppositely, having a negative effect on a country's comparative advantage in unskilled labour-intensive goods. These scenarios apply the Heckscher-Ohlin principle with respect to relative endowments of

\footnotetext{
${ }^{2}$ Consistent with this line of argument, Owens and Wood argue that it is the higher average education levels of Latin America compared to sub-Saharan Africa (the numerator of their skill to land ratio taken by itself) that make it viable for Latin America but not sub-Saharan Africa to compete in world markets for processed primary goods (Owens and Wood 1997).

${ }^{3}$ Based on the definition of East Asia used in the ILO database on the economically active population, which includes China, Hong Kong (China), Japan, Macau (China), Mongolia, the Democratic People’s Republic of Korea and the Republic of Korea.

${ }^{4}$ From the viewpoint of a household's decision as to whether to send a child to school or work, the effect of education on broader economic outcomes, such as export performance or economic growth, are regarded as "externalities" (Basu 1999, p. 1095; Sherburne 2001, p. 362). From the viewpoint of the development policy, however, these are not externalities at all but rather intended policy outcomes.
} 
unskilled labour. As Sherburne writes, "The use of child labour is modeled as an endowment increase in unskilled labour. Although there may be additional considerations that could possibly be introduced, it is the endowment effect that is considered as the most important aspect in describing the economy-wide economic implications of child labour" (ibid., p. 362). The additional considerations referred to by Sherburne are the substitutability of child and adult labour, the "nimble fingers" argument, and earnings discrimination against children. Regarding the effect of child labour on trade through earnings discrimination against children, it is worth noting that this is only relevant for children working in export sectors, and the percentage of children working here is estimated to be small, around five percent (Brown, Deardorff and Stern 1999, p. 6). ${ }^{5}$ For these reasons this study, as others, estimates the effect of child labour on trade using aggregate measures of child labour.

It is questionable, though, whether child labour has much bearing on manufacturing exports via the workings of the Heckscher-Ohlin principle. Of fundamental importance in this regard are the insights of Wood, who writes, "To understand North-South trade and labour markets, a minimum of three skill categories appears to be essential” (Wood 1994, p. 48). Wood describes these three categories as follows:

The first category contains workers with no (or virtually no) schooling.... There are few such workers in the North, but they account for about two-fifths of the total labour force in the South. These uneducated people work mainly in agriculture or other traditional activities, and are generally unsuited to manufacturing and other modern activities, which require at least literacy or primary schooling. Workers who have such a basic general education, but no more, are the second skill category.... They are described as "unskilled" in the North, but in the South this term is ambiguous, because it fails to distinguish [between these first two skill categories].... The third category...includes all workers with substantial post-basic education and training (ibid., pp. 48-49).

Wood goes on to refer to this first category of unskilled workers as "unemployable in manufacturing" and argues that countries having many such workers "are unlikely to have a comparative advantage in manufacturing, making the distributional effects of lower trade barriers ambiguous" (ibid., p. 60).

There are two important points worth bearing in mind regarding Wood's views, corresponding to two competing causal channels through which child labour might affect manufacturing exports - the Heckscher-Ohlin causal channel with respect to relative endowments of unskilled labour and the education causal channel. The first point is that insofar as child labour belongs in Wood's first category of unskilled workers - part of the two-fifths of the South's total labour force - changes in the supply of child labour will not affect manufacturing exports through the Heckscher-Ohlin causal channel. In other words, a decline in child labour will not have a negative effect on a country's comparative advantage in unskilled labour-intensive manufactures because the unskilled labour market in which children work is not, by and large, the unskilled labour market that matters for manufacturing exports. Consistent with this point are cross-country studies finding no relationship between wages in manufacturing as well as other sectors (accounting for labour productivity) and the same or similar indicators of child labour used in this paper (Belser 2001; Kucera 2001). The

\footnotetext{
${ }^{5}$ Recent ILO estimates are that 8.3 percent of child labour is in manufacturing, 70.4 percent in agriculture, hunting, forestry and fishing, 18.6 percent in various services, 1.9 percent in construction, and 0.8 percent in mining and quarrying (ILO 2002b, p. 23).
} 
second point is that education and literacy matter for all manufacturing exports, even those classified as unskilled labour-intensive manufacturing exports. Owen and Wood write, for instance, that it "appears to be the case [that] illiterate workers are not productive in shirt or shoe factories" (Owen and Wood 1997, p. 1467). Wood also surveys studies of workers in export sectors in Malaysia, Mexico, the Philippines, Singapore, the Republic of Korea, and Sri Lanka, all of which show these workers having quite high levels of educational attainment (Wood 1994, p. 95).

Taking all the above together, insofar as child labour belongs in Wood's first category of unskilled workers, then the Heckscher-Ohlin causal channel between child labour and manufacturing exports is inoperative; and insofar as education is inversely related to child labour, one ought to expect more child labour to result in lower manufacturing exports through the education causal channel, including exports of unskilled labour-intensive manufactures. In short, one would not expect a reduction in child labour to have a negative effect on unskilled labour-intensive manufacturing exports but rather a positive effect. The main findings of this paper are consistent with this expectation and show that higher levels of education and less child labour are associated with more manufacturing exports. Moreover, coefficient estimates on measures of education and child labour are not found to differ greatly between total manufacturing exports and unskilled labour-intensive manufacturing exports. This similarity between unskilled labour-intensive manufacturing exports and the manufacturing average is not what one would expect if child labour and education affected comparative trade advantage for unskilled labour-intensive manufactures and suggests rather that, at least within manufacturing, the effect of child labour and education is more through absolute trade advantage.

The remainder of the paper is structured as follows. Section 2 surveys prior cross-country econometric studies addressing the effects of child labour and education on international trade. Section 3 describes the indicators of child labour and education in this study. Section 4 describes the gravity trade model and industry classifications by the labour and skill intensity of production. Section 5 presents empirical results based on different industry classifications, with and without regional dummy variables, and addressing various other types of sensitivity analysis as well as the regional variation of results. Section 6 concludes.

\section{Prior empirical evidence}

In surveying prior empirical evidence, we focus on studies that use indicators related to child labour and education in econometric models evaluating trade between richer and poorer countries. Four such studies are of particular interest: Rodrik (1996), Belser (2001), Busse (2002 and Flanagan (2003). ${ }^{6}$

\footnotetext{
${ }^{6}$ For studies evaluating the effect of trade openness - as measured by the ratio of exports plus imports to national income - on child labour - as measured by the economic activity rate of ten to fourteen year olds, see Shelburne (2001), Cigno, Rosati and Guarello (2002), Edmonds and Pavcnik (2004) and Neumayer and de Soysa (2004). Shelburne and Neumayer and de Soysa find statistically significant negative relationships between trade openness and child labour using these measures. Edmonds and Pavcnik also find negative though not statistically significant relationships, after accounting for the association between trade openness and per capita income. Cigno, Rosati and Guarello, in contrast, find positive though not robustly statistically significant relationships using these measures of trade
} 


\section{Rodrik (1996).}

Rodrik constructs a trade model with the ratio of textile and clothing exports to other exports (excluding fuels) as the dependent variable using data for the mid-1980s and with samples of up to eighty-three countries. ${ }^{7}$ The two independent variables used in the benchmark model are the population-to-land ratio and average years of education for the population over twenty-five year of age, measures of relative labour endowments and human capital, respectively. Into this benchmark model is introduced a variable for child labour based on coding United States Department of Labor reports for which 0 equals no reported problems with either legislation or enforcement of child labor laws, 1 equals reported problems with either legislation or enforcement, and 2 equals reported problems with both legislation and enforcement. For full samples of countries as well as for samples of developing countries, coefficient estimates are consistently positive, consistent with the view that more child labor is associated with a comparative advantage in textile and clothing exports. However, these coefficient estimates are not statistically significant for the full sample of countries and are not consistently statistically significant for the sample of developing countries (depending on the inclusion of other labour standards-related variables in the model).

\section{Belser (2001).}

Belser constructs a trade model with a ratio of skill-intensive to unskilled-intensive manufacturing exports as the dependent variable using data for the first half of the 1990s and with samples of up to sixty-four countries. ${ }^{8}$ Belser's benchmark model is basically the average years of education for the population over fifteen year of age, in which he includes indicators of labour standards other than child labour. Belser's measure of child labour is a dummy variable based on the residual of the economic activity rate of ten to fourteen year olds regressed on per capita income, which takes the value of 1 if the incidence of child labour is higher than the predicted incidence and 0 otherwise. For both full samples of countries and samples of developing countries, Belser finds that more child labour by this measure is associated with a higher ratio of skill-intensive to unskilled-intensive manufacturing exports, though results are statistically significant only for the full sample of countries. These findings are at odds with the hypothesis that more child labour has a negative effect on comparative trade advantage for skill-intensive manufactures. Belser also finds, contrarily, a positive association between years of education and the ratio of skillintensive to unskilled-intensive manufacturing exports, though this relationship does not remain statistically significant upon the inclusion in the model of per capita income.

openness and child labour. Some of these studies also use other measures of trade openness and child labour and come to varying findings.

${ }^{7}$ With sample size for all studies surveyed here based on the inclusion in the model of at least one variable for child labour or education.

${ }^{8}$ With skill intensity as defined by Wood and Mayer (1998). 


\section{Busse (2002).}

Busse constructs a trade model with a ratio of unskilled labour-intensive manufacturing exports to total manufacturing exports as the dependent variable using data for the late-1990s and with samples of up to eighty-three countries. ${ }^{9}$ The two independent variables used in the benchmark model are the labour force-to-land ratio and an educational attainment index, based on the literacy rate and the average years of education for the population over twentyfive years of age. Coefficient estimates on the educational attainment index merit comment. For both full samples of countries and samples of developing countries, Busse finds statistically significant negative relationships between this index and the ratio of unskilled labour-intensive manufacturing exports to total manufacturing exports. Busse uses the economic activity rate of ten to fourteen year olds as his measure of child labour. Inversely to the result on the educational attainment index (and excluding this index from the model), Busse finds a statistically significant result that more child labour is associated with higher ratios of unskilled labour-intensive manufacturing exports to total manufacturing exports, consistent with the view that more child labor is associated with a comparative advantage in unskilled labour-intensive manufacturing exports.

\section{Flanagan (2003).}

Flanagan constructs a trade model with the ratio of total exports to GDP as the dependent variable using data for the first half of the 1980s and with samples of up to eighty countries. Flanagan uses in his benchmark model the population-to-land ratio and the average years of educational attainment for the population over twenty-five year of age. In addition, he includes in his benchmark model a measure of the change in the terms of trade for merchandise, a measure of the average distance to the capital cities of countries with the largest exports, and dummy variables for openness, being an island and being landlocked. Though Flanagan does not include in his model a measure of child labour, he does find a statistically significant result that higher average years of educational attainment is associated with higher total export to GDP ratios.

Taken together, these studies come to mixed findings regarding the effects of child labour and education on trade and comparative trade advantage. Busse's results provide the strongest contrast with the findings of our study, given that he uses one of the same measures of child labour and a similar measure of education and finds statistically significant coefficient estimates pointing in the opposite direction.

\footnotetext{
${ }^{9}$ With unskilled labour-intensive manufacturing industries defined in section 4.2.
} 


\section{Indicators of child labour and education}

This paper employs four indicators for education (including two sex-weighted versions) and two for child labour, using data for 1995 or the nearest available year. For education, these are:

- Years of educational attainment. Data constructed by Barro and Lee on the average years of educational attainment for those fifteen years of age and older.

- Literacy rate. The adult literacy rate from UNESCO, defined as "the percentage of population aged 15 years and over who can both read and write with understanding a short simple statement on his/her everyday life" (UNESCO website).

These data are made available with breakdowns by sex. We use these breakdowns to construct sex-weighted years of educational attainment and literacy variables, using ILO estimates of female and male shares of the economically activity population as weights. These weighted versions thus provide estimates of the education of the workforce rather than the population as a whole.

The two indicators of child labour are:

- Economic activity rate for ten to fourteen year olds. ILO estimates of the percentage of the population from ten to fourteen years of age, inclusive, that is economically active.

- Secondary education non-enrollment rate. The secondary gross education enrollment data from UNESCO subtracted from 100 to get the non-enrollment rate, with the gross education enrollment rate defined as "Total enrolment in a specific level of education, regardless of age, expressed as a percentage of the eligible official school-age population corresponding to the same level of education in a given school-year" and which "can be over $100 \%$ due to the inclusion of over-aged and under-aged pupils/students because of early or late entrants, and grade repetition" (UNESCO website). As such, the non-enrollment rate can be a negative number. We use the gross rather than net enrollment rate as it is available for a substantially larger number of countries.

The secondary education non-enrollment rate refers to children of roughly the same age as the economic activity rate and provides a useful complement to this rate for which measurement error is "particularly problematic at the tails of the age distribution" (Mehran 2000, p. xi). The secondary education non-enrollment rate is recommended as an indicator of child labour by Bescond, Chataignier and Mehran (2003), partly on the grounds that, taken as a worldwide average, the number of children combining work with school is nearly the same as the number of children neither at work nor school, at around ten percent. ${ }^{10}$

\footnotetext{
${ }^{10}$ It is also worth noting that the number of economically active children is larger than the number of child labourers as defined by the ILO. As the ILO writes, "Child labour is a narrower concept than ‘economically active children', excluding all those children 12 years and older who are working only a
} 
Correlation coefficients between the above indicators and also GDP per capita in US dollar and PPP terms are shown in Table 1. Note the strong correlations between the education and child labour indicators and GDP per capita, especially in PPP terms, consistent with the view that there are important developmental aspects of education and child labour. There are also large negative correlation coefficients between the education and child labour indicators, ranging between -0.730 and -0.854 in value, illustrating the strong inverse relationship between education and child labour.

Descriptive statistics for these variables are shown in Table 2 with regional breakdowns, showing highest education levels and least child labour in the old OECD (pre-1990s) and transition regions and the opposite in sub-Saharan Africa and South Asia, with other regions in between. Table 2 also shows the number of observations for each of these variables and the number of countries within each region. Note that there are considerably fewer observations for years of educational attainment than for other variables and thus that regressions using this measure address a substantively different sample of countries.

\section{The trade model and industry classifications by labour and skill intensity}

\subsection{The gravity model of international trade}

We employ a gravity trade model to evaluate the relationship between child labour, education and international trade. It is referred to as a gravity model in analogy with the determinants of the strength of gravitational pull, in that the volume of trade between countries is hypothesized to be positively determined by a country's "mass" and negatively determined by the distance between countries. Rose describes the empirical success as well as multiple theoretical foundations of the gravity trade model as follows:

The gravity model of international trade has a remarkably consistent (and thus, for economics, unusual) history of success as an empirical tool.... Indeed in their recent survey on the empirics of international trade, Leamer and Levinsohn (1995, p. 1384) describe the gravity model as having provided "...some of the clearest and most robust empirical findings in economics.”... While originally an entirely empirical model, the gravity model can now claim theoretical foundations. In fact, numerous theoretical aspirants have claimed the singular empirical success of the gravity model. These include: the "Armington" model of nationally differentiated goods; models with increasing returns and monopolistic competition; models with national technological differences; "reciprocal dumping" models of homogenous goods; and models with internationally varying factor endowments (Rose 1999, p. 8).

The consistency of the gravity model with trade theory based on relative factor endowments and the Heckscher-Ohlin principle and also other trade theories is shown by Anderson (1979), Bergstrand (1985, 1989), Deardorff (1998), Feenstra, Markusen and Rose (1998) and

few hours a week in permitted light work and those 15 years and above whose work is not classified as 'hazardous' (ILO 2002a, in summary of highlights). According to recent ILO estimates, 88.4 percent of the world's economically active children from five to fourteen years of age, inclusive, are child labourers (ibid.). 
Evenett and Keller (2002). This theoretical consistency is relevant for our study in that we evaluate not just total trade but manufacturing industry trade with breakdowns by the labour intensity of production. The suitability of the gravity model for our purposes is suggested, for instance, by our inclusion of independent variables for population and land area, which in the context of our specification provide identical controls for relative endowments of labour and land as Rodrik (1996) and Flanagan (2003).

Our study relies on Rose (1998) and Van Beers (1997) regarding model specification - for both core gravity and supplemental independent variables - as well as sensitivity analysis. We follow Van Beers (and differ from Rose) in taking as the dependent variable exports from one country to another (rather than total trade between pairs of countries as in Rose), and consequently independent variables are constructed, whenever it is meaningful to do so, in pairs for exporting and importing countries, including for indicators of child labour and education. We take this approach because, as with Van Beers, this facilitates evaluating the relationship between labour standards in a country and that country's exports.

Our model basically refers to the 1993 to 1997 period. Exports however are for the 1993 to 1999 period, providing a somewhat lagged response to independent variables and yielding a slightly better modelling fit. For bilateral trade data, we rely on the World Trade Analyzer database. ${ }^{11}$ Following the conventions of this database, we evaluate samples of up to 135 "countries," eight of which are in fact comprised of groups of countries or regions. Thus the full sample is actually made up of 162 countries or regions, for which there are discrete data for 135 (see Appendix: Data notes). For the sake of expediency, we refer to these simply as "countries" or each as a "country" hereafter.

The equation for the benchmark trade model is:

$$
\log \left(1+\text { exports }_{x m}\right)=
$$

$$
\begin{aligned}
& c+\log \left(\text { distance }_{x m}\right)+\log (\text { GDP/cap })+\log \left(G D P / \text { cap }_{m}\right)+\log \left(\text { pop }_{x}\right)+\log \left(\text { pop }_{m}\right)+ \\
& \log \left(\text { area }_{x}\right)+\log \left(\text { area }_{m}\right)+\text { common border }_{x m}+1 \text { landlocked }_{x m}+2 \text { landlocked }_{x m}+1 \\
& \text { island }_{x m}+2 \text { island }_{x m}+R T A_{x m}+\text { exchange rate }(88-92)_{x m}+\varepsilon \text {, }
\end{aligned}
$$

where $\log$ refers to the natural logarithm, $\boldsymbol{c}$ is a constant, $\varepsilon$ is an error term, $\boldsymbol{x}$ refers to the exporting country, $\boldsymbol{m}$ refers to the importing country, and the definitions of the remaining variables are as follows, with the conventional expected signs of coefficient estimates on independent variables in parentheses.

exports $_{x \boldsymbol{m}}=$ exports from country $\boldsymbol{x}$ to country $\boldsymbol{m}$, annual average for the 1993 to 1999 period in thousands of current US dollars. The 1 is added so that zero trade values are not dropped from the sample and yields about 800 additional observations for total trade and total manufacturing trade.

\footnotetext{
${ }^{11}$ The World Trade Analyzer database provides data only on gross exports, a potential limitation of which is pointed out by Jörg Mayer, who writes that "taking gross exports could be a problem because the data may be inflated by exports within international production networks that have a high import content and that may be produced in export processing zones with potentially different labour standard legislation than the rest of the economy” (personal correspondence).
} 
distance $_{x m}=$ surface (great circle) distance between the geographic centers of countries $\boldsymbol{x}$ and $\boldsymbol{m}$ in miles (negative).

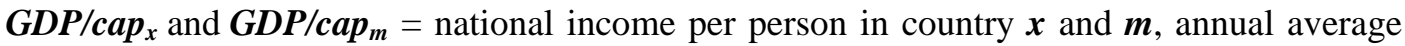
for 1993 to 1997 in current US dollars (positive for both).

$\boldsymbol{p o p}_{\boldsymbol{x}}$ and $\boldsymbol{p o p}_{\boldsymbol{m}}=$ population in country $\boldsymbol{x}$ and $\boldsymbol{m}$, annual average for the 1993 to 1997 period (positive for both).

Taken together with $\mathbf{G D P} / \mathbf{c a p}_{\boldsymbol{x}}$ and $\mathbf{G D P} / \boldsymbol{c a p}_{\boldsymbol{m}}, \boldsymbol{p o p}_{\boldsymbol{x}}$ and $\boldsymbol{p o p}_{\boldsymbol{m}}$ make up the measures of country "mass" and the four together with distance $_{x m}$ make up the core gravity model, with the remaining independent variables of a supplemental nature as regards the extent of work done in accounting for cross-country variation in trade.

$\boldsymbol{a r e a}_{x}$ and $\boldsymbol{a r e a}_{\boldsymbol{m}}=$ land area in square kilometers (negative for both).

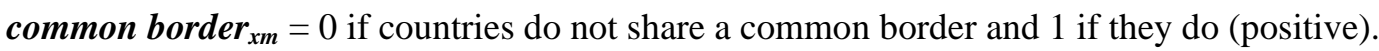

1 landlocked $_{x m}=1$ if one of the two countries is landlocked and 0 otherwise (negative).

2 landlocked $_{x m}=1$ if both of the countries are landlocked and 0 otherwise (negative).

1 island $_{x m}=1$ if one of the two countries is an island and 0 otherwise (positive).

2 island $_{x m}=1$ if both of the countries are islands and 0 otherwise (positive).

$\boldsymbol{R T A}_{\boldsymbol{x} \boldsymbol{m}}=0$ if countries are not in a regional trade agreement and 1 if they are (positive). ${ }^{12}$

exchange rate (88-92) $)_{x m}=$ exchange rate volatility between country $x$ and $\boldsymbol{m}$, constructed as the standard deviation of the monthly log growth rate of the bilateral exchange rate for the 1988 to 1992 period (negative). ${ }^{13}$

Main regressions are done with and without conventional regional dummy variables (in pairs with countries as both exporters and importers), for the sake of testing the robustness of results and facilitating comparison with previous studies. These regional dummy variables are for Latin America-Caribbean, non-OECD East Asia-Pacific (referred to as East Asia hereafter), South Asia, the transition countries, Sub-Saharan Africa, and Middle East-North

\footnotetext{
${ }^{12}$ This includes all types of regional trade agreements as of March 2001except those for services. In addition to this variable was tested a variable for tariffs for exporting and importing countries, defined as import duties as a percentage of imports. However this variable was missing for many countries in our sample and so reduced the number of observations by roughly half. For total trade and total manufacturing trade, moreover, the coefficient estimate on tariffs for importing countries was not statistically significant, and it is these tariffs that are expected to have the most direct impact on exporting countries.

${ }^{13}$ Exchange rates are given against the US dollar in the IMF International Financial Statistics, which we convert to bilateral form. In addition to the 1988 to 1992 period, we also tested this same variable constructed for the 1993 to 1997 period and found that its coefficient estimate was not statistically significant.
} 
Africa. The excluded region is for countries that were OECD members prior to 1990 (also applicable for the non-OECD East Asia-Pacific regional dummy variable). Coefficient estimates on the included regional dummy variables should be interpreted relative to this excluded region. Into the benchmark models are then introduced, one at time, the six different indicators of child labour and education, in pairs for exporting and importing countries. ${ }^{14}$

Econometric results are based on ordinary least squares and weighted least squares estimation, with standard errors derived using White corrections. Results reported are coefficient estimates and significance symbols (two-tailed, with *,**, and *** indicating significance at 10, 5, and 1 percent levels, respectively), and - for benchmark regressions only $-t$-statistics on coefficient estimates, the number of observations ("N" in tables), adjusted $R^{2} \mathrm{~s}$, and $F$-statistics.

\title{
4.2 Industry classifications by labour and skill intensity and benchmark model results
}

We evaluate trade with breakdowns for total trade, total manufacturing trade, and, within manufacturing, for labour-intensive, capital-intensive and in-between industries. ${ }^{15}$ We also evaluate unskilled labour-intensive manufacturing industries. Within manufacturing, regressions rely largely on industry classifications by labour intensity of our own construction. We classify manufacturing industries into labour-intensive, capital-intensive and in-between industries, which sum to the manufacturing total. This was done as follows. Labour coefficients were created as five-year annual averages for the 1993 to 1997 period for those countries or regions that were the largest merchandise exporters and importers as of

\begin{abstract}
${ }^{14}$ Rather than using GDP per capita and population as paired measures of country "mass," one could also use GDP per capita and GDP, as in Rose (1999), or GDP and population, as in Van Beers (1998) (in which case the expected signs of coefficient estimates on population are argued by Van Beers to be negative, on the grounds that "a country with a large population can much easier specialize in a wide range of commodities and, consequently, will be less dependent on foreign trade” (ibid., p. 64)). We prefer our specification on the grounds that GDP per capita and population are the least correlated of the three possible pairs and provide intuitively additive elasticities with respect to trade flows. That is, export and import potential are positively determined by the number of persons in a country plus the average domestic product (regarding exports) or income (regarding imports) per person in a country (though coefficient estimates on these variables lend themselves to different theoretical interpretations (Bergstrand 1989; Deardorff 1995; and Evenett and Keller 1998)). Practically speaking, however, it makes no difference in this particular context which pair one chooses, as any pair yields very near identical coefficient estimates and standard errors on all other independent variables in the model.
\end{abstract}

One could also substitute for the natural logarithm of land area the natural logarithm of the ratio of population to land area, as per Rodrik (1996) and Flanagan (2003) (and similar to Belser (2001) and Busse (2001)). Doing so yields coefficient estimates of identical magnitude but opposite sign between these variables, slightly smaller coefficient estimates on $\log \left(\boldsymbol{p o p}_{x}\right)$ and $\log \left(\boldsymbol{p o p}_{\boldsymbol{m}}\right)$, and identical coefficient estimates on all other variables. As such, reversing the sign on log $\left(\boldsymbol{a r e a}_{x}\right)$ in our specification provides an estimate of the effect of relative endowments of labour to land on exports. For manufacturing trade with breakdowns by labour intensity, these coefficient estimates turn out to be consistent with the Heckscher-Ohlin principle with respect to labour and land.

\footnotetext{
${ }^{15}$ In the World Trade Analyzer database, total trade differs from manufacturing trade mainly in that it includes primary goods - that is, agricultural goods and non-agricultural raw materials.
} 
1995 and for which there were no problems with the availability of data. We focus on these countries as it is their experience that provides the clearest sense of what it takes to be successful in international goods markets. This yielded a group of twenty-nine countries or regions. The labour coefficients were constructed largely at the three-digit ISIC (International Standard Industrial Classification) Rev. 2 level using the UNIDO Industrial Statistics Database. The exception is that we created a separate industry that combines office, computing and accounting machinery (ISIC 3825) and radio, television and communication equipment (ISIC 3832), as these goods figure importantly in exports from developing to developed countries. We rank these twenty-nine industries by taking the average ordinal ranking of labour coefficients across countries. For the main regressions, we classify the top nine industries as labour-intensive, the middle eleven as in-between, and the bottom nine as capital-intensive. $^{16}$

This method yields what seem to be reasonable industry classifications, shown in Table 3. Labour-intensive industries are similar to those characterized as such by other studies and include the needle trades and other light manufacturing for which the product can generally be readily conveyed by hand (cf. Cutler, Berri and Ozawa (2003) for an overview of previously-used classifications of labour-intensive manufacturing industries). Most fundamentally regarding the debates on trade and labour standards, all industries classified as labour-intensive are those for which there do not appear to be prohibitive technological barriers preventing poorer developing countries from competing in international goods markets, at least for many types of products within each of these industries. This is in general contrast with industries we have classified as capital-intensive or in-between. All industries categorized as capital-intensive are those for which the product lends itself to production by

\footnotetext{
${ }^{16}$ The list of largest merchandise exporters and importers is from The Economist Intelligence Unit's World Trade Report (EIU, 1996), which treats the EU 15 as a single unit. The countries or regions used to construct industry rankings are Australia, Brazil, Austria, Canada, China, Denmark, Finland, France, Greece, Hong Kong (China), Indonesia, Ireland, Italy, Japan, Malaysia, Mexico, Netherlands, Norway, Portugal, Russia, Singapore, the Republic of Korea, Spain, Sweden, Taiwan (China), Thailand, Turkey, the United Kingdom and the United States. Data are also available for Germany, India and Saudi Arabia, but the first two were excluded because their labour coefficients tended to be weakly correlated with those of other countries or regions and Saudi Arabia was excluded because of its high share of oil exports. Data for Australia are from 1992, as these data were not available for the 1993 to 1997 period. Turkey is the only country of the twenty-nine that is on the importer list but not the exporter list.
}

We constructed industry classifications both by employment to value added ratios and employment to output ratios. In practice, the difference between the two classifications comes to little. Most importantly, the labour-intensive industry group remains identical. The only difference in the other industry groups is that food products and paper and paper products move in opposite directions from capital-intensive to in-between industries depending on which ratio is used. However, we have a slight preference for the use of employment to output ratios and so use these as the basis of industry classifications. This better groups like industries alike (food products with beverages and tobacco products in capital-intensive industries; paper and paper products with printing and publishing in inbetween industries) and to some extent addresses comparative advantage based not only on relative factor endowments, as per the Heckscher-Ohlin principle, but also in terms of technological capacity. Employment to output ratios combine the more-purely labour cost (and thus Heckscher-Ohlin) considerations of employment to value added ratios with Chandlerian technological considerations regarding the throughput rate of intermediate goods as suggestive of the prevailing technology in an industry (Chandler 1977). 
highly automated "continuous-process" technologies (Chandler 1977). In between are all machinery-producing industries, a set of closely-allied industries making rubber and plastic products, glass and glass products, and other non-metallic mineral products, as well as printing and publishing and paper and paper products. ${ }^{17}$

It is fairly straightforward to rank and group industries by labour intensity, for which one only needs industry-level data on employment and output. It is considerably more problematic to rank and group industries by skill intensity given the paucity of industry-level data directly measuring skills. Yet given that each of our three industry groups has a qualitative coherence regarding type of process technology, we also take them to provide a sense of the skill intensity of production. Most important, we take our labour-intensive manufacturing industries as providing a sense of unskilled labour-intensive manufacturing industries.

In addition to our own classification scheme, we use a categorization of labour-intensive and capital-intensive manufacturing industries constructed by UNIDO (1981) and employed by Van Beers (1998). We put manufacturing industries that are classified as neither labourintensive nor capital-intensive by UNIDO into an in-between category such that three categories sum to the manufacturing total. The two most important data sources used to construct this classification scheme are for India (based on capital per employee) and the US (based on value added per employee) using data for the year 1965.

We also use two additional industry classifications that are specifically referred to as addressing unskilled labour-intensive manufacturing industries. First is that used by Busse (2002, which is comprised of textile yarn and fabrics (SITC 65), glass, glassware and pottery (664-666), furniture and bedding (82), travel goods and handbags (83), apparel (84), footwear (85) and baby carriages, games, toys and sporting goods (894). Note that all the component industries of this group are contained within our labour-intensive industry group with the exception of glass and glass products (ISIC 362 or SITC 664, 665), which we include in the in-between industry group. The classification by labour intensity is based on Tyres, Phillips and Findlay (1987), which is derived from value added per worker. The classification by skill is based on OECD (2001), which is derived from research and development expenditures relative to output and which the OECD describes as addressing technology rather than skill as such. It is worth noting though that the OECD classification of industries is based solely on data for OECD countries and can therefore only provide a rough sense of the skills required by workers in developing countries. For example, office, accounting and computing machinery (ISIC 30) and radio, television and communications equipment (ISIC 32) are classified as "high-technology" manufacturing industries according to the OECD scheme. However, research and development expenditures in these industries in OECD countries, much for new product development, tell one little about how products in these industries are produced in developing countries and thus tell one little about the actual skills required to produce them.

\footnotetext{
${ }^{17}$ Note that some of the industries we have classified as in-between might also be classified as “continuous process," such as paper - combined with paper products in ISIC 341 - and glass combined with glass products in ISIC 362 (Chandler 1977, p. 353). However regression results are broadly similar between our in-between and capital-intensive industries, and thus reclassification between these industry groups should not have a substantive effect on results.
} 
The second industry classification specifically referred to as addressing unskilled labourintensive manufacturing industries is that used by Krause (1987). Krause's classification is comprised of textile yarn and fabrics (SITC 65), non-metallic mineral manufactures (66), furniture and bedding (82), travel goods and handbags (83), apparel (84) and footwear (85). Note that all its component industries are contained within our labour-intensive industry group except for non-metallic mineral manufactures (SITC 66), which in our classification is split between labour-intensive and in-between industries. Krause's classification also differs from our labour-intensive industry group and that employed by Busse in that it does not include baby carriages, games, toys and sporting goods (SITC 894). ${ }^{18}$ It is important to note, though, that Krause's classification is based on Garnaut and Anderson (1980), which is derived solely from value added per worker and thus does not directly address skill intensity.

The correspondence between our industry classification (ISIC Rev. 2) and the World Trade Analyzer data (SITC Rev. 2) is shown in appendix Table 1 and is based on a correspondence table produced by the United Nations (2003). This table also shows the correspondence between Busse's and Krause's industry classifications and our own.

Results of benchmark models for total trade, total manufacturing trade, and the three manufacturing industry groups by labour and skill intensity are shown in Tables 4 and 5, respectively without and with regional dummy variables. For the sake of expediency, we refer hereafter to results on the three manufacturing industry groups by labour intensity, with the understanding that they also refer to an extent to skill intensity. Focusing in Table 4 on total trade and total manufacturing trade, we see that coefficient estimates are of the expected sign and generally statistically significant for at least one of the two trade categories (the strongest exception is for $\mathbf{1}$ island $_{\boldsymbol{x m}}$, for which the coefficient estimate is not significantly different from zero, a result also found in Rose (1999)). After accounting for missing values, bilateral trade among the 135 countries yields around 14,000 observations. Adjusted $R^{2}$ s are greater than 0.70, similar to Rose's model evaluating 1990 data (1999). However, most of the variation in bilateral trade is captured by the model's core variables of $\log \left(\right.$ distance $\left._{x m}\right), \log$ $\left(G D P / c_{a p}\right), \log \left(G D P / c a p_{m}\right), \log \left(\right.$ pop $\left._{x}\right)$ and $\log \left(\boldsymbol{p o p}_{m}\right)$. Coefficient estimates on these core variables provide elasticities that hover around unity, and $t$-statistics on all are greater than forty-five. ${ }^{19}$ Looking at Table 5 for total trade and total manufacturing trade in the benchmark model including regional dummies, note that statistical significance is lost for the coefficient estimates on $\boldsymbol{R T A}_{x m}$ and exchange rate (88-92) groups within manufacturing trade.

For total trade and total manufacturing trade, there are statistically significant positive coefficient estimates on the regional dummy variables for East Asia and South Asia as exporters. (We also graphically show coefficient estimates for regional dummy variables for each of the six developing regions in figure 2.) Coefficient estimates are particularly large for

\footnotetext{
${ }^{18}$ The only exception to this regarding our classification and Busse's is that we include SITC 8946 not under ISIC 390 but rather under ISIC 382 minus 3825, as per the UN (2003) correspondence table, and the latter industry we classify as in-between.

${ }^{19}$ It is worth noting that for manufacturing trade with breakdowns by labour intensity, reversing the sign on coefficient estimates on $\log \left(\boldsymbol{a r e a}_{\boldsymbol{x}}\right)$ provides estimates of the effects of relative endowments of labour to land on exports. These are consistent with the Hecksher-Ohlin principle as regards these factors of production, being largest for labour-intensive manufacturing trade and smallest for capitalintensive manufacturing trade.
} 
East Asia, suggesting that the region exports nearly four times more total manufacturing trade than the OECD region, after accounting for determinants of trade as per the model. ${ }^{20}$ Moreover, East Asia is estimated to have high relative exports for all three manufacturing industry groups, ranking highest to lowest by labour-intensive, in-between, and capitalintensive manufacturing industries. This pattern accords with the view that East Asian export success has come to be diversified across a wide range of manufacturing industries. Note too that these coefficient estimates are a good deal larger than those for the regional dummy variable for East Asia as an importer and indeed that the estimate for East Asia as an importer is negative for labour-intensive trade. This pattern of diversification for East Asia as an exporter contrasts with South Asia as an exporter, for which there are significantly high relative exports only for labour-intensive manufactures.

The strong positive coefficient estimate on the regional dummy variable for East Asia suggests a potential problem in the interpretation of the causal determinants of trade. For in the absence of regional dummy variables, coefficient estimates on any measure introduced into the trade model tending to have similar values for countries in the East Asia region might suggest that this measure is a causal determinant of export performance (depending on the extent to which variation in the measure is captured by other variables in the model and how the measure varies for other countries). A very similar question of interpretation occurred in the empirical literature on the effects of income inequality on long-run economic growth. While several earlier studies found evidence that greater income inequality had a negative impact on long-run economic growth, this result was not found to be robust with respect to the inclusion of regional dummy variables (Deininger and Squire 1998). This was also a story of Asia, which has relatively low income inequality and relatively high growth rates. As with this literature, we regard results for models including regional dummy variables as more definitive in that they control for unspecified cross-regional variation and are driven by crosscountry variation. However, we present main results with and without regional dummy variables, which facilitates comparison with prior studies surveyed above that did not include regional dummy variables.

\section{Empirical findings}

\subsection{Main results}

The child labour and education indicators are introduced one by one into the benchmark models. Each indicator is introduced pairwise for the exporting and importing country (as with $\log$ (GDP/cap), $\log$ (pop) and $\log$ (area) in the benchmark models). Shown in Table 6 are coefficient estimates on the child labour and education indicators for the exporting country in the context of the benchmark models, with and without regional dummy variables and using the four industry group classifications. Given space constraints, our presentation focuses hereafter on these coefficient estimates, which provide estimates of the effects of child labour and education on exports while bilaterally controlling for child labour and education in the importing country. Light shading indicates that less child labour and more education are associated with significantly higher exports (10 percent level or higher), and

\footnotetext{
${ }^{20} \mathrm{e}^{1.362}=3.90$, where 1.362 is the coefficient estimate on the dummy variable for total manufacturing trade for East Asia as an exporter.
} 
dark shading indicates that more child labour and less education are associated with significantly lower exports.

Looking at the full set of results in Table 6 shows a preponderance of light shading for both education and child labour indicators. The only dark shading is for one cell in the upper-right panel, for the coefficient estimate on the economic activity rate for ten to fourteen year olds for in-between manufacturing exports, based on our own industry classification and without regional dummy variables. For the four education variables (including those unweighted and weighted by female and male shares of the economically active population), coefficient estimates are generally more strongly positive (further from zero) including regional dummy variables; for the two child labour variables, in contrast, coefficient estimates are generally less strongly negative (closer to zero) without regional dummy variables. Results on years of educational attainment and literacy are very similar between unweighted and weighted versions. Results on years of educational attainment are weakest using Krause's and Busse's definitions of labour-intensive manufacturing industries and including regional dummy variables, where coefficient estimates remain positive but are no longer statistically significant. Otherwise, coefficient estimates on the four education variables in the other six panels of the table are of similar magnitude. For both child labour and education variables, we also find similar coefficient estimates between total manufacturing exports and labourintensive manufacturing exports. (The exception, again, is for results on years of educational attainment using Krause's and Busse's definitions of labour-intensive manufacturing industries and including regional dummy variables.) That is, labour intensive manufacturing exports are not particularly sensitive to the effects of child labour and education compared to the manufacturing average, which is more consistent with a story of absolute rather than comparative trade advantage.

Overall, Table 6 presents quite consistent evidence that less child labour and more education are associated with higher exports, using four definitions of the labour intensity of production and with or without regional dummy variables. That said, we believe we have reasonable grounds for taking as most definitive those results based on our own classification of industries by labour intensity and including regional dummy variables in the model. Similarly with the income inequality-growth literature, we argue that regional dummy variables belong in the model so that results are driven by cross-country variation rather than unspecified cross-regional variation that may be proxied by any measure that countries in a region tend to have in common.

Regarding industry classifications, we prefer our classification to the UNIDO classification in that it is based on more countries and more up to date data. Regarding Krause's and Busse's industry classifications, one concern is that both classify the glass and glass products industry as labour-intensive, which we argue is not generally fitting for the products from these industries that figure most importantly in international trade. ${ }^{21}$ More generally, it is important that any ranking of industries by labour or skill intensity use qualitative criteria to determine appropriate thresholds and thus industry groups. This is particularly so from the viewpoint of poorer developing countries, for which it seems preferable to include as wide a range of labour-intensive industries as possible, providing the industries do not impose prohibitive technological barriers to production for international markets. This criterion holds true for

\footnotetext{
${ }^{21}$ In our twenty-nine industry ISIC classification, for instance, glass and glass products ranked twelfth by employment to output ratios and seventeenth by employment to value-added ratios.
} 
each of the industries we have classified as labour-intensive, or at least for a great many of the goods produced within them. The groups we classify as capital-intensive and in-between also have a qualitative coherence as regards the type of process technology. It is on these grounds that we prefer modelling results based on our own industry classification and including regional dummy variables, and we proceed accordingly with interpretation of the size of coefficient estimates and sensitivity analysis. As regards differences in industry classification, this of course does not affect results for total trade or total manufacturing trade.

We take coefficient estimates from the upper-left panel of Table 6 to derive estimates of changes in total manufacturing exports associated with changes in education and child labour using example pairs of countries within regions as reference points, shown in Table 7. More specifically, we estimate the percent change and absolute change in total manufacturing exports if an example country within a region were to increase education levels or reduce child labour to the equivalent of another example country in a region that does better in these departments. Within Latin America-Caribbean, we take as example pairs Paraguay and Uruguay; within non-OECD East Asia, Indonesia and the Republic of Korea; within South Asia, Pakistan and India; within Sub-Saharan Africa, Tanzania and Zimbabwe; and within Middle East-North Africa, Egypt and Jordan. For each of these country pairs, the country listed first has lower levels of education and more child labour by the measures used.

For Paraguay and Uruguay, for example, if education in the former as measured by the years of educational attainment were to increase to the level of the latter, our results suggest that this would lead to an estimated 9.25 percent increase in total manufacturing exports, equivalent to 29 million (current) US dollars for Paraguay, relative to actual 1999 exports. The comparable figures are of the same order of magnitude for education measured by the literacy rate and a somewhat larger order of magnitude for child labour measured by the economic activity rate for ten to fourteen year olds. The comparable figures are considerably larger for the secondary education non-enrollment rate, suggesting that if child labour by this measure were reduced in Paraguay to the level of Uruguay, this would lead to an estimated 54.02 percent increase in total manufacturing exports, equivalent to 169 million (current) US dollars for Paraguay, relative to actual 1999 exports.

Indonesia and the Republic of Korea provide an interesting example pair because of the considerable difference between the two countries regarding education and child labour and because Indonesia has large manufacturing export volumes. To take the two measures yielding the more conservative results, education measured by the literacy rate and child labour measured by the economic activity rate, if Indonesia were to improve to the level of the Republic of Korea, it is estimated that this would lead to a 22 percent increase in total manufacturing exports, equivalent to about 7.5 billion (current) US dollars, relative to actual 1999 exports. The comparable figures are a good deal larger for education measured by years of educational attainment and child labour measured by the secondary education nonenrollment rate.

These estimates are meant to be suggestive and one should not take them too literally. The regression coefficient estimates, for instance, apply to the average country, and there is no such thing as an average country. Nonetheless, they provide a sense that there may be nonnegligible trade benefits resulting from with higher education levels and less child labour. 
Table 8 presents findings from different tests of the sensitivity of results based on our preferred specification, for comparison with the upper-left panel of Table 6. We first drop the measure of exchange rate volatility from the model as this variable is missing for a number of countries, and results remain nearly identical. Next, we use weighted least squares estimation. This procedure is generally used as a correction for heteroskedasticity, which we address with White corrections. Following Rose, we use weighted least squares to give greater weight to the observations of larger countries, using both the natural logarithm of $\left(\boldsymbol{G D} \boldsymbol{P}_{\boldsymbol{x}} \boldsymbol{G D P}_{\boldsymbol{m}}\right)$ and $\left(\boldsymbol{p o p}_{\boldsymbol{x}} \boldsymbol{p o p}_{\boldsymbol{m}}\right)$ as weights. Here too, results remain nearly identical. We then look at data for females and males separately, dropping the education indicators weighted by female and male shares of the economically active population. Here we see more substantial changes in the coefficient estimates on years of educational attainment for labour-intensive and inbetween manufacturing exports, but otherwise coefficient estimates are very similar and overall signs and patterns of statistical significance remain unchanged.

Years of educational attainment and literacy represent the accumulation of years of prior education, and thus one would not expect them to be endogenous with respect to contemporary trade and thus for there to be simultaneity bias on their respective coefficient estimates. This differs for child labour, for which there is a significant theoretical and empirical literature addressing the effects of trade on child labour (e.g., Brown, Deardorff and Stern 1999; Shelburne 2001; Cigno, Rosati and Guarello 2002; Edmonds and Pavcnik 2004; and Neumayer and de Soysa 2004). Yet the direction of simultaneity bias on coefficient estimates on child labour is not obvious, both because of the theoretically ambiguous effect of trade on child labour and because of the ambiguity of empirical results. In reviewing the theoretical literature, Edmonds and Pavcnik summarize the theoretical ambiguity as follows:

The review of theory work suggests that the overall effect of trade on child labor depends on how trade affects income, how income affects child labor, how trade affects the relative return to child labor, and how child labor responds to changes in its relative return. If trade increases income and child labor declines with increasing income, then a growth in trade should put downward pressure on child labor. However, trade also likely increases the relative demand for unskilled labor in developing countries and thereby puts upward pressure on child labor (ibid., p. 7).

We address the possibility of simultaneity bias by evaluating lagged economic activity rates for ten to fourteen year olds, going back decade-by-decade from 1990 to 1950 and repeating results using 1995 data for the sake of comparison. ${ }^{22}$ Results are shown in the lower-left panel of Table 8 and are similar whether using 1980, 1990 or 1995 data. For data for 1950, 1960 and 1970, however, we now see statistically significant relationships for in-between manufacturing exports, showing more child labour associated with lower exports. Our interpretation of this result is that child labour acts on exports largely through the education of the workforce, with children from these earlier decades coming to make up the core of the workforce by the 1990s.

Last, we examine patterns of regional variation by dropping one region at a time from the sample including taking China as a region unto itself, shown in Table 9. Overall, the pattern of statistical significance remains very much the same, with the exception of coefficient

22 We do not also evaluate lagged secondary education non-enrollment rates because of data availability constraints. 
estimates on years of education attainment for capital-intensive manufacturing exports. For instance, dropping the sub-Saharan Africa or Latin America-Caribbean regions from the sample, these coefficient estimates remain positive but are no longer statistically significant. Results change more dramatically upon exclusion of the pre-1990s OECD region (and dropping the Latin America-Caribbean regional dummy variable from the model), for which the sample then refers to developing countries, with Turkey being the only developing country in the older OECD region. Here, coefficient estimates on years of education attainment for capital-intensive manufacturing exports become significantly negative and this carries over compositionally to affect results on total exports and total manufacturing exports, for which coefficient estimates remain positive but lose their statistical significance.

It is useful to know, though, whether it is the exclusion of the older OECD countries as importers or exporters that leads to this result. Excluding the older OECD countries as importers and including them as exporters, the coefficient estimates on years of educational attainment for capital-intensive manufacturing exports are positive, as for the full sample of countries, but not statistically significant. Results from excluding the older OECD countries as exporters but including them as importers are shown in the lower-right panel of Table 9. This panel is of particular relevance from the viewpoint of developing countries, as it includes all countries in the sample as importers but only developing countries as exporters. Here the coefficient estimates on years of educational attainment for capital-intensive manufacturing exports are negative but small and not close to statistically significant. Note that coefficient estimates on years of educational attainment are largest for labour-intensive manufacturing exports (and about twice as large as for the full sample of countries), about the same between total manufacturing and in-between manufacturing exports, and basically zero for capital-intensive manufacturing exports.

If we take these three industry classifications as indicative of not only labour but also skill intensity, these patterns suggest that for developing countries years of educational attainment matter most for unskilled labour-intensive manufacturing exports. Note also that, as for the full sample of countries, the coefficient estimate on the economic activity rate for ten to fourteen year olds is more strongly negative for labour-intensive manufacturing exports than for the other trade categories, analogously suggesting that child labour most adversely affects labour-intensive manufacturing exports. However, coefficient estimates between labourintensive manufacturing exports and other trade categories are more similar for the literacy and secondary education non-enrollment rates. More generally, with the exception of years of educational attainment, coefficient estimates are very similar between the full sample of countries and the sample including only developing countries as exporters.

\section{Conclusions}

This paper provides robust statistical evidence that child labour is bad and education is good for exports, including for unskilled labour-intensive manufacturing exports for which results are generally similar to total manufacturing exports. These findings hold for both full samples of developed and developing countries and for samples including only developing countries as exporters. Though these findings are contrary to those of Busse (2002), it is worth noting though that our study contains twice as many countries in the sample, and we also believe that the use of the gravity trade model provides a more solid foundation for our findings. 
We also believe that our results are theoretically reasonable. We contrast two causal channels through which child labour might affect exports, particularly unskilled labour-intensive manufacturing exports. These are the Heckscher-Ohlin causal channel with respect to relative endowments of unskilled labour and the education causal channel, with the former suggesting that more child labour would lead to increased unskilled labour-intensive manufacturing exports and the latter suggesting the opposite. But the work of Wood provides grounds for calling into question the Heckscher-Ohlin causal channel (1994). That is, in developing countries there are at least three fundamental skill categories of workers, two of which are conventionally lumped together as unskilled. Only the more skilled of the two unskilled categories is relevant for manufacturing exports, and child labourers do not - by and large fit into this category as they generally do not have the necessary skills to produce manufacturing exports, including so-called unskilled labour-intensive manufacturing exports. Thus an increase in child labour would not increase the relevant endowment of unskilled labour that matters for manufacturing exports and would not thus affect a country's comparative advantage in unskilled labour-intensive manufactures through the HeckscherOhlin causal channel. On the other hand, there is a strong consensus among otherwise contrary schools of thought that education played a critical role in East Asia's development success, regarding the growth of manufacturing exports and economic growth more generally. Since education and child labour are strongly inversely related across countries, it is the education causal channel that we regard as the more plausible of the two causal channels, and we interpret our results accordingly. 


\section{References}

Amsden, Alice. 2001. The Rise of "The Rest": Challenges to the West from LateIndustrializing Economies. New York: Oxford University Press.

Anderson, James. 1979. “A Theoretical Foundation for the Gravity Equation,” in American Economic Review 69(1), pp.106-116.

Basu, Kaushik. 1999. "Child Labour: Cause, Consequence, and Cure, with Remarks on International Labour Standards," in Journal of Economic Literature 37(3), pp. 1083-1119.

Belser, Patrick. 2001. Four Essays on Trade and Labour Standards, unpublished Ph.D. dissertation, University of Sussex.

Bergstrand, Jeffrey. 1985. "The Gravity Equation in International Trade: Some Microeconomic Foundations and Empirical Evidence," in Review of Economics and Statistics 67(3), pp. 474-481.

Bergstrand, Jeffrey. 1989. “The Generalized Gravity Equation, Monopolistic Competition, and the Factor-Proportions Theory in International Trade," in Review of Economics and Statistics 71(1), pp. 143-153.

Bescond, David, Anne Chataignier and Farhad Mehran. 2003. "Seven Indicators to Measure Decent Work: An International Comparison,” in International Labour Review 142(2), pp. 179-211.

Brown, Drusilla, Alan Deardorff and Robert Stern. 1999. "U.S. Trade and Other Policy Options and Programs to Deter Foreign Exploitation of Child Labour," University of Michigan Research Seminar in International Economics Discussion Paper No. 433.

Busse, Matthias. 2002. "Do Labor Standards Affect Comparative Advantage?” in World Development 30(11), pp. 1921-1932.

Chandler, Alfred. 1977. The Visible Hand: The Managerial Revolution in American Business. Cambridge, Massachusetts: Harvard University Press.

CIA website. The World Factbook 2000. www.cia-gov/cia/publications/factbook. Washington, DC: Central Intelligence Agency.

Cigno, Alessandro, Furio Rosati and Lorenzo Guarcello. 2002. "Does Globalization Increase Child Labor?” in World Development 30(9), pp. 1579-1589.

Cutler, Harvey, David Berri and Terutomo Ozawa. 2003. "Market Recycling in LaborIntensive Goods, Flying-geese Style: An Empirical Analysis of East Asian Exports to the U.S.," in Journal of Asian Economics 14(1), pp. 35-50.

Deardorff, Alan. 1998. "Determinants of Bilateral Trade: Does Gravity Work in a Neoclassical World?” in Jeffrey Frenkel (ed.), The Regionalization of the World Economy. Chicago: The University of Chicago Press. 
Deininger, Klaus and Lyn Squire. 1998. "New Ways of Looking at Old Issues: Inequality and Growth,” in Journal of Development Economics 57(2), pp. 259-287.

Di Caprio, Alisa and Alice Amsden. 2004. "Does the New International Trade Regime Leave Room for Industrialization Policies in the Middle-Income Countries?” ILO Policy Integration Department, Working Paper No. 22.

Edmonds, Eric and Nina Pavcnik. 2004. "International Trade and Child Labor: CrossCountry Evidence,” NBER Working Paper No. 10317.

EIU. 1996. World Trade Report (fourth quarter). London: The Economist Intelligence Unit.

Evenett, Simon and Wolfgang Keller. 2002. "On Theories Explaining the Success of the Gravity Equation,” in Journal of Political Economy 110(2), pp. 281-316.

Feenstra, Robert, James Markusen and Andrew Rose. 1998. "Understanding the Home Market Effect and the Gravity Equation: The Role of Differentiating Goods,” NBER Working Paper No. 6804.

Flanagan, Robert. 2003. "Labor Standards and International Competitive Advantage," in Robert Flanagan (ed.) International Labor Standards: Globalization, Trade and Public Policy. Stanford, California: Stanford University Press.

Galli, Rossana. 2001. “The Economic Impact of Child Labour,” International Institute for Labour Studies, Working Paper No. 128.

Garnaut, Ross and Kym Anderson. 1980. "ASEAN Export Specialization and the Evolution of Comparative Advantage in the Western Pacific Region," in Ross Garnaut (ed.) ASEAN in a Changing Pacific and World Economy. Miami: Australian National University Press.

Gormly, Sarah and Kenneth Swinnerton. 2004. "The Effect of Adult Returns to Schooling on Children's School Enrollment, Theory and Evidence from South Africa,” mimeo (June 22).

ILO. 1996. ILO Economically Active Population 1950-2010, fourth edition. Geneva: International Labour Office.

ILO. 2002a. Every Child Counts: New Global Estimates on Child Labour. Geneva: International Labour Office.

ILO. 2002b. A Future Without Child Labour: Global Report Under the Follow-up to the ILO Declaration on Fundamental Principles and Rights at Work. Geneva: International Labour Office.

IMF. 2002. IMF International Financial Statistics, version 1.1.54. Washington, D.C.: International Monetary Fund.

IPEC. 2003. Investing in Every Child: An Economic Study of the Costs and Benefits of Eliminating Child Labour. Geneva: International Labour Office.

Kucera, David. 2001. "The Effects of Core Worker Rights on Labour Costs and Foreign Direct Investment: Evaluating the 'Conventional Wisdom,"” International Institute for Labour Studies, Working Paper No. 130. 
Krause, Lawrence. 1987. "The Structure of Trade in Manufactured Goods in the East and Southeast Asian Region,” in Colin Bradford Jr. and William Branson (eds.) Trade and Structural Change in Pacific Asia. Chicago: University of Chicago Press.

Leamer, Edward E. and James Levinsohn. 1995. "International Trade Theory: The Evidence,” in Gene M. Grossman and Kenneth Rogoff (eds.) The Handbook of International Economics, Vol. III. Amsterdam: Elsevier Science.

Levin, Andrew and Lakshmi Raut. 1997. "Complementarities between Exports and Human Capital in Economic Growth: Evidence from the Semi-industrialized Countries," in Economic Development and Cultural Change 46(1), pp. 155-174.

Mehran, Farhad. 2000. "ILO Labour Force Participation Rates for 10-14 Years Old Versus UNESCO School Enrolment Ratios,” in ILO Bulletin of Labour Statistics, No. 3, pp. xi-xxi.

Neumayer, Eric and Indra de Soysa. 2004. "Trade Openness, Foreign Direct Investment and Child Labor," revised May 2004, forthcoming in World Development.

Noland, Marcus and Howard Pack. 2003. Industrial Policy in an Era of Globalization: Lessons from Asia. Washington, DC: Institute for International Economics.

OECD. 2001. OECD Science, Technology and Industry Scoreboard: Towards a Knowledgebased Economy. Paris: OECD.

Owens, Trudy and Adrian Wood. 1997. "Export-oriented Industrialization Through Primary Processing?,” in World Development 25(9), pp. 1453-1470.

Rodrik, Dani. 1996. "Labor Standards in International Trade: Do They Matter and What Do We Do About Them?” in Robert Lawrence, Dani Rodrik, and John Whalley (eds.) Emerging Agenda for Global Trade: High Stakes for Developing Countries. Washington, D.C.: Overseas Development Council.

Rose, Andrew. 1999. "One Money, One Market: Estimating the Effects of Common Currencies on Trade,” NBER Working Paper No. 7432.

Shelburne, Robert. 2001. "An Explanation of the International Variation in the Prevalence of Child Labour," in The World Economy 24(3), pp. 359-378.

Statistics Canada. 2001. World Trade Analyzer, 1980-1999. Ottawa: Statistics Canada International Trade Division.

Tyres, Rodney, Prue Phillips and Christopher Findlay. 1987. "ASEAN and China Exports of Labor-intensive Manufactures: Performance and Prospects,” in ASEAN Economic Bulletin 3(3), pp. 339-367.

UN. 2003. 2000 Industrial Commodity Statistics Yearbook: Production Statistics (19912000). New York: United Nations.

UNDP. 1998. UNDP Human Development Report 1998. New York: United Nations Development Programme. 
UNESCO. 1998. UNESCO Statistical Yearbook 1998. Paris: United Nations Educational, Scientific and Cultural Organization.

UNESCO. 1999. UNESCO Statistical Yearbook 1999. Paris: United Nations Educational, Scientific and Cultural Organization.

UNIDO. 1981. World Industry in 1980. New York: United Nations.

UNIDO. 2000. UNIDO Industrial Statistics Database. Vienna: United Nations Industrial Development Organization.

UNIDO. 2001. UNIDO Industrial Statistics Database. Vienna: United Nations Industrial Development Organization.

Van Beers, Cees. 1998. "Labour Standards and Trade Flows of OECD Countries," in The World Economy 21(1), pp. 57-73.

Wade, Robert. 2003. Governing the Market: Economic Theory and the Role of Government in East Asian Industrialization, second paperback edition. Princeton: Princeton University Press.

Wood, Adrian. 1994. North-South Trade, Employment and Inequality: Changing Fortunes in a Skill-Driven World. Oxford: Clarendon Press.

Wood, Adrian and Kersti Berge. 1997. "Exporting Manufactures: Human Resources, Natural Resources, and Trade Policy,” in The Journal of Development Studies 34(1), pp. 35-59.

Wood, Adrian and Jörg Mayer. 1998. "Africa's Export Structure in Comparative Perspective," in UNCTAD Economic Development and Regional Dynamics in Africa: Lessons from the East Asian Experience. Geneva: United Nations Conference on Trade and Development.

World Bank. 1993. The East Asian Miracle: Economic Growth and Public Policy. New York: Oxford University Press.

World Bank. 2001. World Development Indicators. Washington, D.C.: World Bank.

World Bank website. International Measures of Schooling Years and Schooling Quality. www.worldbank.org/research/growth/ddbarle2.htm. Washington, DC: World Bank.

WTO website. www.wto.org. Geneva: World Trade Organization. 
Tables \& Figures 
Table 1: Correlation coefficients (Pearson) between GDP per capita and indicators of child labour and education: mid-1990s

\begin{tabular}{|c|c|c|c|c|c|c|c|c|}
\hline & $\begin{array}{c}\text { GDP/cap } \\
\text { (US\$) }\end{array}$ & $\begin{array}{c}\text { GDP/cap } \\
(\text { PPP) }\end{array}$ & $\begin{array}{c}\text { Years of } \\
\text { educ. }\end{array}$ & $\begin{array}{c}\text { Years of } \\
\text { educ. } \\
\text { weighted } \\
\text { by MF EA }\end{array}$ & $\begin{array}{c}\text { Literacy } \\
\text { rate }\end{array}$ & $\begin{array}{c}\text { Literacy rate } \\
\text { weighted by } \\
\text { MF EA }\end{array}$ & $\begin{array}{l}\text { EA rate for } \\
10-14 \text { year } \\
\text { olds }\end{array}$ & $\begin{array}{l}\text { 2nd educ. } \\
\text { non- } \\
\text { enrollment } \\
\text { rate }\end{array}$ \\
\hline 1 GDP/cap (US\$) & 1.000 & & & & & & & \\
\hline 2 GDP/cap (PPP) & 0.960 & 1.000 & & & & & & \\
\hline 3 Years of educ. & 0.714 & 0.786 & 1.000 & & & & & \\
\hline 4 Years of educ. weighted by MF EA & 0.701 & 0.759 & 0.980 & 1.000 & & & & \\
\hline 5 Literacy rate & 0.538 & 0.639 & 0.838 & 0.780 & 1.000 & & & \\
\hline 6 Literacy rate weighted by MF EA & 0.533 & 0.637 & 0.836 & 0.780 & 0.997 & 1.000 & & \\
\hline 7 EA rate for $10-14$ year olds & -0.513 & -0.628 & -0.769 & -0.730 & -0.794 & -0.811 & 1.000 & \\
\hline 8 2nd educ. non-enrollment rate & -0.729 & -0.819 & -0.854 & -0.799 & -0.784 & -0.790 & 0.798 & 1.000 \\
\hline
\end{tabular}

Sources: See Appendix: Data Sources.

Note: The critical two-tailed values for 98 degrees of freedom (100 observations) are 0.164, 0.195 and 0.254 at the 10, 5 and 1 percent levels, respectively. 
Table 2: Descriptive statistics for GDP per capita and indicators of child labour and education: mid-1990s

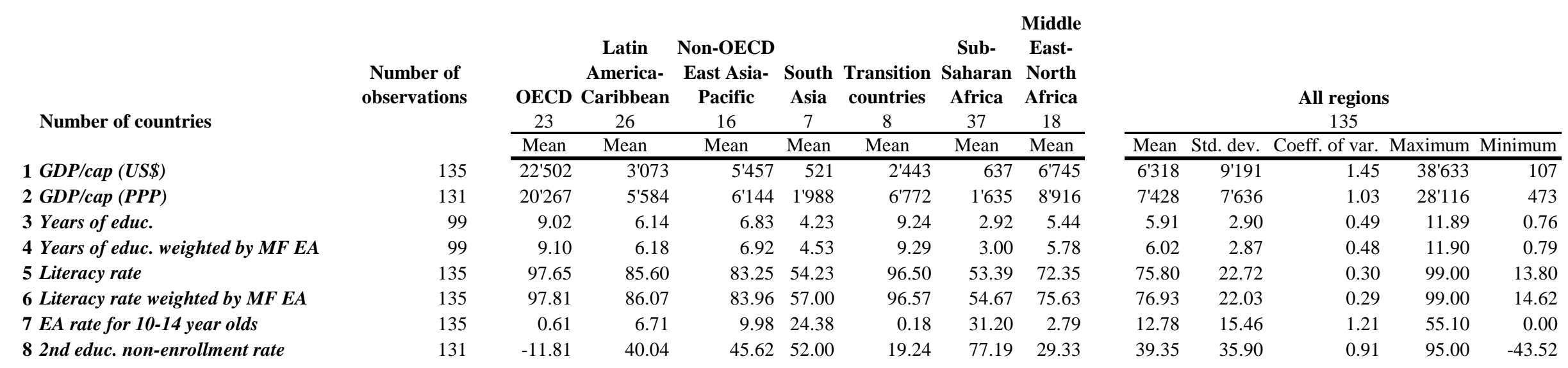

Sources: See Appendix: Data Sources. 
Table 3: Manufacturing industry classification by labour intensity

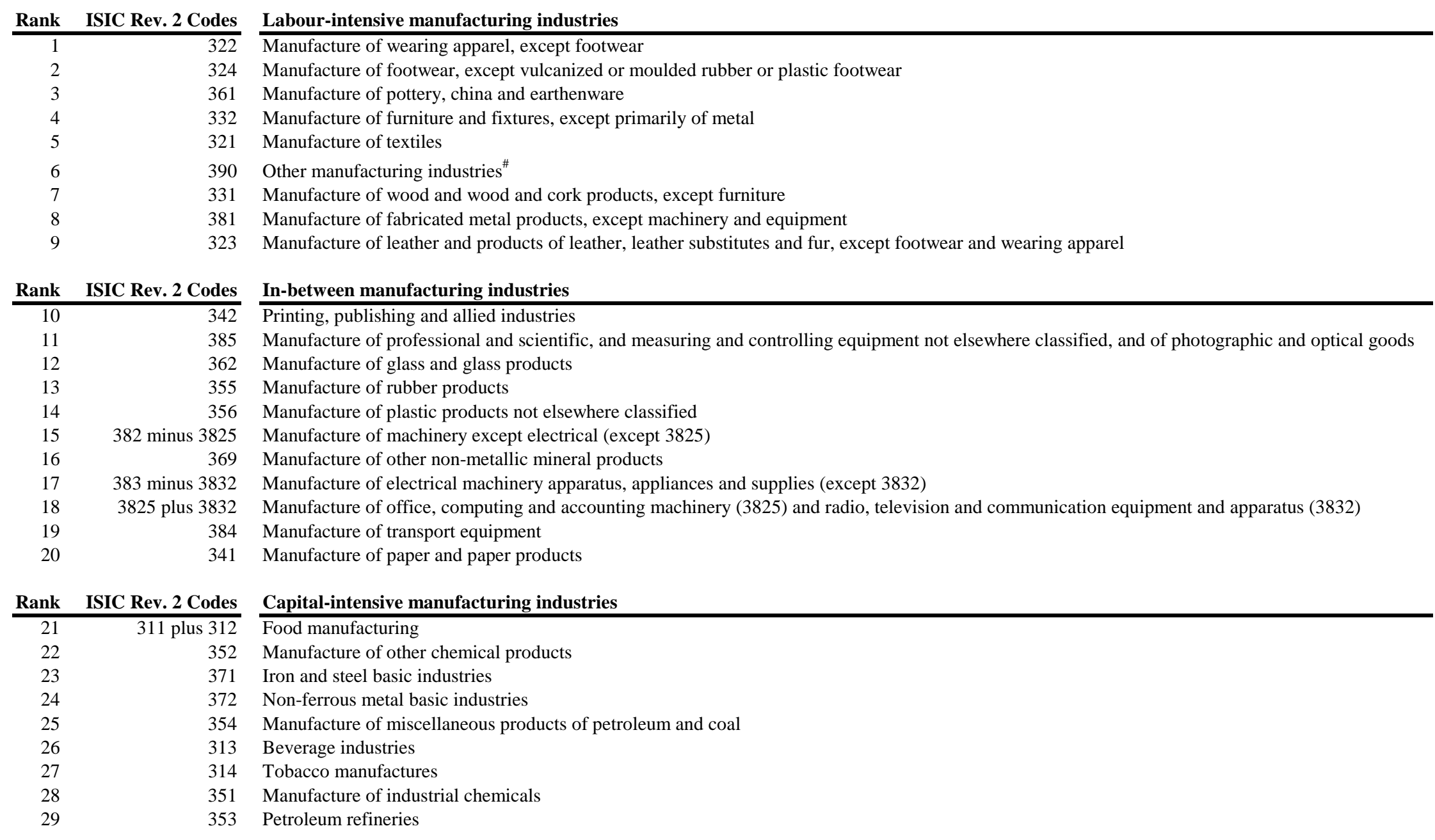

Source: Full industry names are from the United Nations Statistics Division, at: http://unstats.un.org/unsd/cr/registry/

Note: ${ }^{\#}$ Comprised of manufacture of jewellery and related articles, musical instruments, sporting and athletic goods, and manufacturing industries not elsewhere classified. 
Table 4: Benchmark trade model results without regional dummy variables

\begin{tabular}{|c|c|c|c|c|c|}
\hline & Total trade & $\begin{array}{c}\text { Total mfg. } \\
\text { trade }\end{array}$ & $\begin{array}{c}\text { Labour- } \\
\text { intensive mfg. } \\
\text { trade }\end{array}$ & $\begin{array}{l}\text { In-between } \\
\text { mfg. trade }\end{array}$ & $\begin{array}{c}\text { Capital- } \\
\text { intensive mfg. } \\
\text { trade }\end{array}$ \\
\hline$c$ & $-35.924 * * *$ & $-34.844 * * *$ & $-32.901 * * *$ & $-34.088 * * *$ & $-30.807 * * *$ \\
\hline & -101.015 & -95.927 & -82.207 & -86.883 & -75.431 \\
\hline \multirow[t]{2}{*}{$\log \left(\right.$ distance $\left._{x m}\right)$} & $-1.325 * * *$ & $-1.357 * * *$ & $-1.238 * * *$ & $-1.317 * * *$ & $-1.419 * * *$ \\
\hline & -48.034 & -48.739 & -42.046 & -44.720 & -46.650 \\
\hline \multirow[t]{2}{*}{$\log \left(G D P / \operatorname{cap}_{x}\right)$} & $1.317 * * *$ & $1.473 * * *$ & $1.132 * * *$ & $1.625 * * *$ & $1.373 * * *$ \\
\hline & 129.927 & 146.283 & 101.768 & 148.498 & 114.706 \\
\hline \multirow[t]{2}{*}{$\log \left(G D P / c a p_{m}\right)$} & $1.056 * * *$ & $0.937 * * *$ & $0.978 * * *$ & $0.771 * * *$ & $0.811 * * *$ \\
\hline & 98.590 & 85.809 & 81.189 & 65.242 & 64.979 \\
\hline \multirow[t]{2}{*}{$\log \left(\operatorname{pop}_{x}\right)$} & $1.302 * * *$ & $1.389 * * *$ & $1.510 * * *$ & $1.427 * * *$ & $1.119 * * *$ \\
\hline & 85.578 & 91.219 & 87.899 & 87.342 & 63.524 \\
\hline \multirow[t]{2}{*}{$\log \left(\operatorname{pop}_{m}\right)$} & $1.107 * * *$ & $0.962 * * *$ & $0.803 * * *$ & $0.764 * * *$ & $0.963 * * *$ \\
\hline & 72.939 & 63.452 & 48.854 & 45.758 & 55.323 \\
\hline \multirow[t]{2}{*}{$\log \left(\operatorname{area}_{x}\right)$} & $-0.124 * * *$ & $-0.206 * * *$ & $-0.373 * * *$ & $-0.243 * * *$ & $-0.054 * * *$ \\
\hline & -10.059 & -17.007 & -27.183 & -18.937 & -4.005 \\
\hline \multirow[t]{2}{*}{$\log \left(\operatorname{area}_{m}\right)$} & $-0.142 * * *$ & $-0.115 * * *$ & $-0.091 * * *$ & $-0.062 * * *$ & $-0.136 * * *$ \\
\hline & -11.749 & -9.420 & -7.008 & -4.649 & -9.671 \\
\hline \multirow[t]{2}{*}{ common border ${ }_{x m}$} & $1.275 * * *$ & $1.351 * * *$ & $1.262 * * *$ & $1.464 * * *$ & $1.299 * * *$ \\
\hline & 9.833 & 10.340 & 9.339 & 11.067 & 9.653 \\
\hline \multirow[t]{2}{*}{1 landlocked $_{x m}$} & $-0.389 * * *$ & $-0.464 * * *$ & $-0.289 * * *$ & $-0.180 * * *$ & $-0.729 * * *$ \\
\hline & -9.001 & -10.773 & -6.094 & -3.896 & -14.449 \\
\hline \multirow[t]{2}{*}{2 landlocked $_{x m}$} & -0.044 & $-0.283 * *$ & $-0.398 * *$ & 0.065 & $-0.696 * * *$ \\
\hline & -0.339 & -2.097 & -2.461 & 0.425 & -4.281 \\
\hline \multirow[t]{2}{*}{1 island $_{x m}$} & 0.008 & 0.002 & $-0.202 * * *$ & 0.061 & $0.089 *$ \\
\hline & 0.174 & 0.050 & -4.036 & 1.223 & 1.690 \\
\hline \multirow[t]{2}{*}{2 island $_{x m}$} & $0.654 * * *$ & $0.713 * * *$ & $0.500 * * *$ & $0.598 * * *$ & $0.814 * * *$ \\
\hline & 4.996 & 5.466 & 3.333 & 4.228 & 5.170 \\
\hline \multirow[t]{2}{*}{$\boldsymbol{R T A}_{x m}$} & 0.067 & $0.089 *$ & $0.250 * * *$ & 0.006 & $0.143 * * *$ \\
\hline & 1.404 & 1.858 & 4.821 & 0.110 & 2.644 \\
\hline \multirow[t]{2}{*}{ exchange rate $(88-92)_{x m}$} & $-0.458 * * *$ & -0.227 & $-0.966 * * *$ & $-0.553 * * *$ & 0.274 \\
\hline & -2.942 & -1.437 & -5.285 & -3.081 & 1.506 \\
\hline $\mathbf{N}$ & $14 ' 574$ & $14 ' 006$ & $11 ' 902$ & 12'158 & $12 ' 412$ \\
\hline Adj. $R^{2}$ & 0.737 & 0.743 & 0.687 & 0.729 & 0.665 \\
\hline$F$-Stat. & 2911.098 & 2889.661 & 1863.300 & 2338.429 & 1763.076 \\
\hline
\end{tabular}

Notes: Bolded numbers indicate regression coefficient estimates, below which are associated $t$-statistics.

$*, * *$ and $* * *$ indicate two-tailed significance at 10,5 and 1 percent levels, respectively. 
Table 5: Benchmark trade model results with regional dummy variables

\begin{tabular}{|c|c|c|c|c|c|}
\hline & Total trade & $\begin{array}{c}\text { Total mfg. } \\
\text { trade }\end{array}$ & $\begin{array}{l}\text { Labour- } \\
\text { intensive mfg. } \\
\text { trade }\end{array}$ & $\begin{array}{c}\text { In-between } \\
\text { mfg. trade }\end{array}$ & $\begin{array}{c}\text { Capital- } \\
\text { intensive mfg. } \\
\text { trade }\end{array}$ \\
\hline$c$ & $-33.306 * * *$ & $-31.867 * * *$ & $-29.580 * * *$ & $-32.085 * * *$ & $-30.022 * * *$ \\
\hline & -68.451 & -65.271 & -56.298 & -60.665 & -52.199 \\
\hline \multirow[t]{2}{*}{$\log \left(\right.$ distance $\left._{x m}\right)$} & $-1.515 * * *$ & $-1.595 * * *$ & $-1.533 * * *$ & $-1.578 * * *$ & $-1.630 * * *$ \\
\hline & -50.684 & -53.428 & -48.947 & -51.828 & -48.549 \\
\hline \multirow[t]{2}{*}{$\log \left(G D P / c a p_{x}\right)$} & $1.413 * * *$ & $1.526 * * *$ & $1.250 * * *$ & $1.628 * * *$ & $1.414 * * *$ \\
\hline & 68.637 & 74.980 & 57.780 & 74.773 & 57.458 \\
\hline \multirow[t]{2}{*}{$\log \left(G D P / c^{\prime a p} p_{m}\right)$} & $1.012 * * *$ & $0.942 * * *$ & $0.977 * * *$ & $0.903 * * *$ & $0.852 * * *$ \\
\hline & 49.470 & 46.717 & 46.169 & 41.866 & 36.318 \\
\hline \multirow[t]{2}{*}{$\log \left(p o p_{x}\right)$} & $1.197 * * *$ & $1.216 * * *$ & $1.249 * * *$ & $1.246 * * *$ & $1.048 * * *$ \\
\hline & 68.967 & 70.774 & 68.554 & 68.712 & 49.987 \\
\hline \multirow[t]{2}{*}{$\log \left(\right.$ pop $\left._{m}\right)$} & $1.094 * * *$ & $0.989 * * *$ & $0.841 * * *$ & $0.817 * * *$ & $1.005 * * *$ \\
\hline & 67.229 & 61.557 & 48.614 & 45.507 & 52.627 \\
\hline \multirow[t]{2}{*}{$\log \left(\operatorname{area}_{x}\right)$} & $-0.063 * * *$ & $-0.104 * * *$ & $-0.197 * * *$ & $-0.158 * * *$ & -0.008 \\
\hline & -4.848 & -8.161 & -14.493 & -11.764 & -0.530 \\
\hline \multirow[t]{2}{*}{$\log \left(\right.$ area $\left._{m}\right)$} & $-0.152 * * *$ & $-0.135 * * *$ & $-0.120 * * *$ & $-0.060 * * *$ & $-0.137 * * *$ \\
\hline & -12.132 & -10.855 & -9.164 & -4.479 & -9.202 \\
\hline \multirow[t]{2}{*}{ common border ${ }_{x m}$} & $0.951 * * *$ & $0.964 * * *$ & $0.821 * * *$ & $1.044 * * *$ & $0.933 * * *$ \\
\hline & 7.057 & 7.128 & 5.854 & 7.759 & 6.753 \\
\hline \multirow[t]{2}{*}{1 landlocked $_{x m}$} & $-0.524 * * *$ & $-0.601 * * *$ & $-0.431 * * *$ & $-0.338 * * *$ & $-0.768 * * *$ \\
\hline & -12.219 & -14.237 & -9.451 & -7.541 & -14.979 \\
\hline \multirow[t]{2}{*}{2 landlocked $_{x m}$} & $-0.308 * *$ & $-0.535 * * *$ & $-0.563 * * *$ & -0.221 & $-0.776 * * *$ \\
\hline & -2.331 & -4.085 & -3.805 & -1.508 & -4.730 \\
\hline \multirow[t]{2}{*}{1 island $_{x m}$} & -0.073 & $-0.080 *$ & $-0.318 * * *$ & 0.008 & $0.088 *$ \\
\hline & -1.642 & -1.796 & -6.649 & 0.178 & 1.675 \\
\hline \multirow[t]{2}{*}{2 island $_{x m}$} & $0.454 * * *$ & $0.521 * * *$ & 0.202 & $0.440 * * *$ & $0.788 * * *$ \\
\hline & 3.610 & 4.174 & 1.456 & 3.396 & 5.094 \\
\hline \multirow[t]{2}{*}{$R T A_{x m}$} & 0.005 & -0.009 & $0.097 * *$ & $-0.081 *$ & 0.034 \\
\hline & 0.106 & -0.200 & 2.012 & -1.695 & 0.639 \\
\hline \multirow[t]{2}{*}{ exchange rate $(88-92)_{x m}$} & -0.184 & -0.132 & -0.291 & $-0.478 * *$ & -0.008 \\
\hline & -1.095 & -0.784 & -1.533 & -2.491 & -0.038 \\
\hline \multirow[t]{2}{*}{ Latin America-Caribbean $_{x}$} & $-0.111 *$ & $-0.202 * * *$ & $-0.132 *$ & $-0.912 * * *$ & $0.271 * * *$ \\
\hline & -1.673 & -3.019 & -1.805 & -12.440 & 3.473 \\
\hline \multirow[t]{2}{*}{ Latin America-Caribbean $_{m}$} & $-0.189 * * *$ & $0.116 *$ & -0.092 & $0.849 * * *$ & $0.422 * * *$ \\
\hline & -2.627 & 1.650 & -1.267 & 11.045 & 5.087 \\
\hline \multirow[t]{2}{*}{ non-OECD East Asia-Pacific ${ }_{x}$} & $1.138 * * *$ & $1.362 * * *$ & $1.992 * * *$ & $1.122 * * *$ & $0.814 * * *$ \\
\hline & 15.066 & 18.110 & 24.683 & 14.148 & 9.312 \\
\hline non-OECD East Asia-Pacific ${ }_{m}$ & 0.102 & $0.156 *$ & -0.133 & $0.673 * * *$ & $0.457 * * *$ \\
\hline & 1.268 & 1.959 & -1.625 & 7.689 & 4.877 \\
\hline South Asia ${ }_{x}$ & $0.656 * * *$ & $0.937 * * *$ & $1.742 * * *$ & -0.085 & 0.231 \\
\hline & 5.875 & 8.452 & 14.649 & -0.695 & 1.642 \\
\hline South Asia $_{m}$ & $-0.535 * * *$ & $-0.511 * * *$ & $-0.605 * * *$ & $0.209 *$ & -0.207 \\
\hline & -4.404 & -4.245 & -4.924 & 1.674 & -1.480 \\
\hline Transition countries $_{x}$ & 0.053 & $0.273 * * *$ & $-0.479 * * *$ & 0.106 & $0.539 * * *$ \\
\hline & 0.647 & 3.330 & -5.107 & 1.174 & 5.593 \\
\hline Transition countries $_{m}$ & $-0.685 * * *$ & $-0.709 * * *$ & $-0.468 * * *$ & $-0.230 * *$ & $-0.506 * * *$ \\
\hline & -7.180 & -7.477 & -4.755 & -2.234 & -4.421 \\
\hline Sub-Saharan Africa ${ }_{x}$ & $0.336 * * *$ & -0.074 & 0.018 & $-0.225 * *$ & 0.073 \\
\hline & 3.626 & -0.802 & 0.191 & -2.293 & 0.652 \\
\hline Sub-Saharan Africa $_{m}$ & $-0.244 * * *$ & 0.113 & 0.061 & $0.752 * * *$ & $0.322 * * *$ \\
\hline & -2.626 & 1.241 & 0.631 & 7.674 & 3.000 \\
\hline Middle East-North Africa ${ }_{x}$ & $-0.711 * * *$ & $-0.855 * * *$ & $-0.837 * * *$ & $-1.413 * * *$ & $-0.614 * * *$ \\
\hline & -10.007 & -12.289 & -11.623 & -19.275 & -7.668 \\
\hline Middle East-North Africa ${ }_{m}$ & $-0.685 * * *$ & $-0.506 * * *$ & $-0.416 * * *$ & $0.169 * *$ & -0.012 \\
\hline & -9.651 & -7.238 & -5.747 & 2.277 & -0.151 \\
\hline $\mathbf{N}$ & $14 ' 574$ & $14 ' 006$ & 11'902 & $12 ' 158$ & $12^{\prime} 412$ \\
\hline Adj. $R^{2}$ & 0.752 & 0.765 & 0.730 & 0.762 & 0.677 \\
\hline$F$-Stat. & 1700.572 & 1756.571 & 1240.367 & 1496.847 & 1003.275 \\
\hline
\end{tabular}

Notes: Bolded numbers indicate regression coefficient estimates, below which are associated $t$-statistics.

$*$, ** and $* * *$ indicate two-tailed significance at 10,5 and 1 percent levels, respectively. 
Table 6: Trade model results by industry classification and with and without regional dummy variables

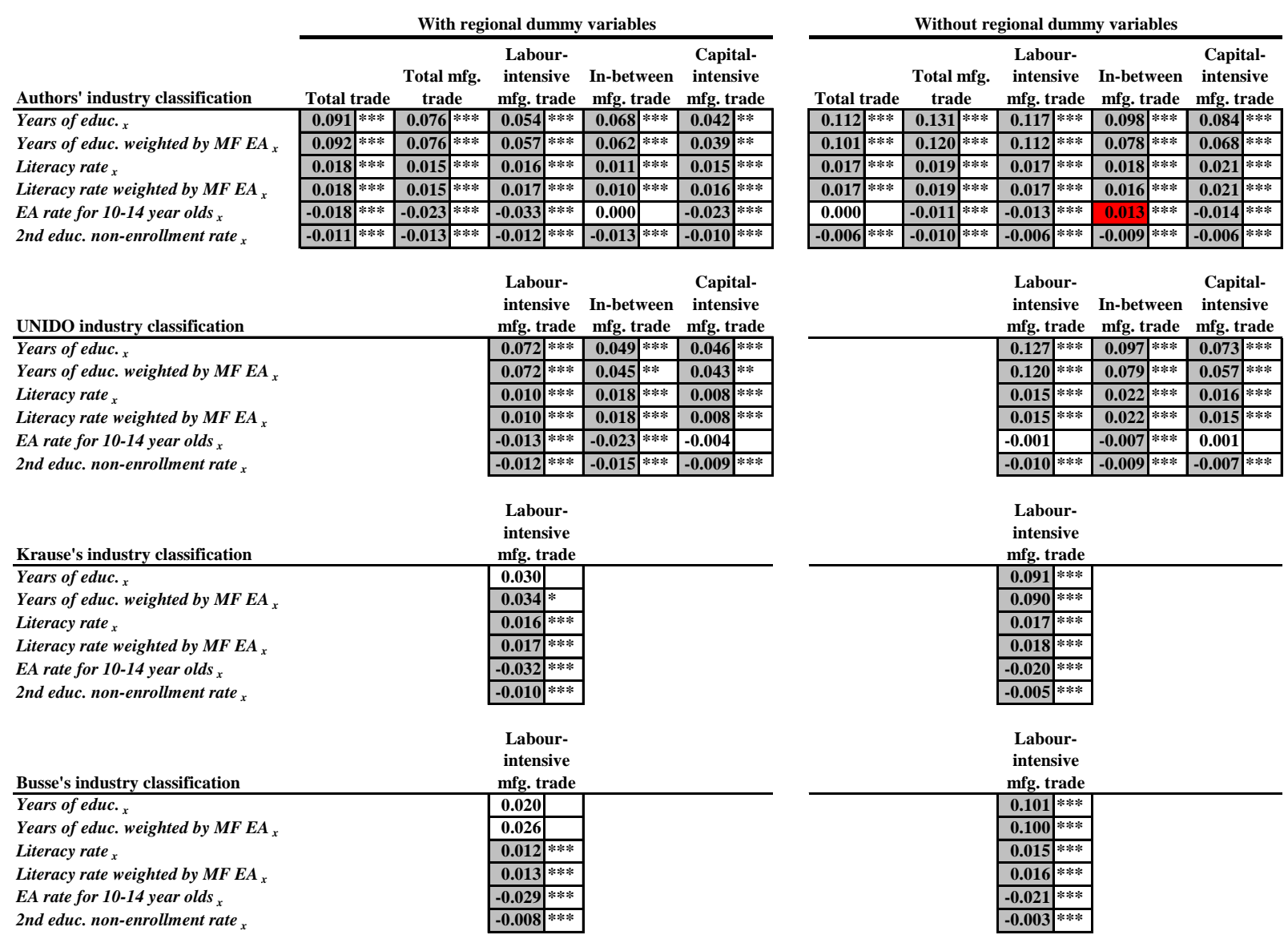

Note: *,** and $* * *$ indicate two-tailed significance at 10,5 and 1 percent levels, respectively.

Light shading indicates that less child labour or more education is associated with significantly higher exports (10 percent level or higher),

while dark shading indicates that more child labour or less education is associated with significantly lower exports. 
Table 7: Changes in total manufacturing exports associated with changes in child labour and education between example pairs of countries within regions

\begin{tabular}{|c|c|c|c|c|}
\hline Sample countries from Latin America-Caribbean & $\begin{array}{l}\text { Years of } \\
\text { educ. } x\end{array}$ & $\begin{array}{c}\text { Literacy } \\
\text { rate }_{x}\end{array}$ & $\begin{array}{c}\text { EA rate } \\
\text { for } 10-14 \\
\text { year olds } s_{x}\end{array}$ & $\begin{array}{l}\text { 2nd educ. } \\
\text { non- } \\
\text { enrollment } \\
\text { rate }_{x}\end{array}$ \\
\hline$\overline{\text { A. Paraguay }}$ & 6.10 & 92.05 & 7.87 & 59.00 \\
\hline B. Uruguay & 7.31 & 97.30 & 2.08 & 18.00 \\
\hline $\begin{array}{l}\text { \% change in total mfg. exports associated with change in } \\
\text { indices from A to B }\end{array}$ & 9.25 & 8.03 & 13.07 & 54.02 \\
\hline $\begin{array}{l}\text { Change in } 1999 \text { total mfg. exports for country A associated } \\
\text { with change in indices from A to B in millions of current US\$ }\end{array}$ & 29 & 25 & 41 & 169 \\
\hline \multicolumn{5}{|l|}{ Sample countries from non-OECD East Asia-Pacific } \\
\hline $\begin{array}{l}\text { A. Indonesia } \\
\text { B. Republic of Korea }\end{array}$ & $\begin{array}{r}4.55 \\
10.56\end{array}$ & $\begin{array}{l}83.82 \\
98.00\end{array}$ & $\begin{array}{l}9.55 \\
0.00\end{array}$ & $\begin{aligned} 48.95 \\
-1.00\end{aligned}$ \\
\hline $\begin{array}{l}\text { \% change in total mfg. exports associated with change in } \\
\text { indices from A to B }\end{array}$ & 45.97 & 21.69 & 21.56 & 65.82 \\
\hline $\begin{array}{l}\text { Change in } 1999 \text { total mfg. exports for country A associated } \\
\text { with change in indices from A to B in millions of current US\$ }\end{array}$ & $16^{\prime} 046$ & 7'571 & 7'526 & $22^{\prime} 973$ \\
\hline \multicolumn{5}{|l|}{ Sample countries from South Asia } \\
\hline A. Pakistan & 3.92 & 37.20 & 17.67 & 74.00 \\
\hline B. India & 4.52 & 51.60 & 14.38 & 51.00 \\
\hline $\begin{array}{l}\text { \% change in total mfg. exports associated with change in } \\
\text { indices from A to B }\end{array}$ & 4.64 & 22.02 & 7.43 & 30.30 \\
\hline $\begin{array}{l}\text { Change in } 1999 \text { total mfg. exports for country A associated } \\
\text { with change in indices from A to B in millions of current US\$ }\end{array}$ & 377 & $1 ' 787$ & 603 & 2 '459 \\
\hline \multicolumn{5}{|l|}{ Sample countries from Sub-Saharan Africa } \\
\hline A. Tanzania & 2.68 & 68.10 & 39.48 & 95.00 \\
\hline B. Zimbabwe & 5.19 & 85.15 & 29.44 & 53.00 \\
\hline $\begin{array}{l}\text { \% change in total mfg. exports associated with change in } \\
\text { indices from A to B }\end{array}$ & 19.20 & 26.08 & 22.67 & 55.34 \\
\hline $\begin{array}{l}\text { Change in } 1999 \text { total mfg. exports for country A associated } \\
\text { with change in indices from A to B in millions of current US\$ }\end{array}$ & 35 & 48 & 42 & 102 \\
\hline \multicolumn{5}{|l|}{ Sample countries from Middle East-North Africa } \\
\hline A. Egypt & 4.99 & 51.20 & 11.22 & 23.00 \\
\hline B. Jordan & 6.47 & 86.40 & 0.68 & 12.00 \\
\hline $\begin{array}{l}\text { \% change in total mfg. exports associated with change in } \\
\text { indices from A to B }\end{array}$ & 11.36 & 53.84 & 23.80 & 14.49 \\
\hline $\begin{array}{l}\text { Change in } 1999 \text { total mfg. exports for country A associated } \\
\text { with change in indices from A to B in millions of current US\$ }\end{array}$ & 274 & 1'300 & 575 & 350 \\
\hline
\end{tabular}

Note: Based on coefficient estimates for total mfg. trade from the upper left panel of table 5.A.

Index values for Indonesia is for this country alone and not for the country groups defined in the data notes appendix. 
Table 8: Trade model sensitivity analysis results

\begin{tabular}{|c|c|c|c|c|c|c|c|c|c|c|c|c|c|c|c|}
\hline \multirow{2}{*}{$\begin{array}{l}\text { Authors' industry classification, w/ } \\
\text { regional dummy variables }\end{array}$} & \multicolumn{2}{|c|}{ Total trade } & \multicolumn{2}{|c|}{$\begin{array}{l}\text { Total mfg. } \\
\text { trade }\end{array}$} & \multicolumn{2}{|c|}{$\begin{array}{l}\text { Labour- } \\
\text { intensive } \\
\text { mfg. trade }\end{array}$} & \multicolumn{2}{|c|}{$\begin{array}{l}\text { In-between } \\
\text { mfg. trade }\end{array}$} & \multicolumn{2}{|c|}{$\begin{array}{c}\text { Capital- } \\
\text { intensive } \\
\text { mfg. trade }\end{array}$} & Total trade & $\begin{array}{l}\text { Total mfg. } \\
\text { trade }\end{array}$ & $\begin{array}{l}\text { Labour- } \\
\text { intensive } \\
\text { mfg. trade }\end{array}$ & $\begin{array}{l}\text { In-between } \\
\text { mfg. trade }\end{array}$ & $\begin{array}{l}\text { Capital- } \\
\text { intensive } \\
\text { mfg. trade }\end{array}$ \\
\hline & \multicolumn{10}{|c|}{ Dropping exchange rate (88-92) $)_{x m}$ from the model } & & & & & \\
\hline Years of educ. $x$ & 0.092 & *** & 0.076 & $* * *$ & 0.052 & $* * *$ & 0.066 & $* * *$ & 0.041 & & & & & & \\
\hline Years of educ. weighted by MF EA $A_{x}$ & 0.093 & *** & 0.076 & $* * *$ & 0.055 & $* * *$ & 0.060 & $* * *$ & 0.039 & ** & & & & & \\
\hline 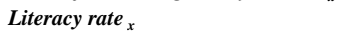 & 0.018 & *** & 0.016 & $* * *$ & 0.016 & *** & 0.010 & $* * *$ & 0.016 & *** & & & & & \\
\hline Literacy rate weighted by $M F E A_{x}$ & 0.018 & *** & 0.016 & $* * *$ & 0.017 & $* * *$ & 0.010 & $* * *$ & 0.016 & *** & & & & & \\
\hline EA rate for 10-14 year olds $x_{x}$ & 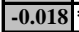 & *** & -0.023 & $* * *$ & -0.033 & $* * *$ & 0.000 & & -0.024 & *** & & & & & \\
\hline 2nd educ. non-enrollment rate ${ }_{x}$ & \begin{tabular}{|l|l|}
-0.012 \\
\end{tabular} & *** & -0.014 & $* * *$ & $\mid-0.013$ & $* * *$ & $\mid-0.014$ & $* * *$ & \begin{tabular}{|l|l|}
-0.012 \\
\end{tabular} & $* * *$ & & & & & \\
\hline $\begin{array}{l}\text { Authors' industry classification, w/ } \\
\text { regional dummy variables }\end{array}$ & \multicolumn{10}{|c|}{ Weighted least squares using $\log \left(G D P_{x} * G D P_{m}\right)$ as weight } & \multicolumn{5}{|c|}{ Weighted least squares using $\log \left(P O P_{x} * P O P_{m}\right)$ as weight } \\
\hline Years of educ. ${ }_{x}$ & 0.088 & $* * *$ & 0.078 & $* * *$ & 0.054 & $* * *$ & 0.072 & $* * *$ & 0.045 & $* *$ & \begin{tabular}{l|l|l|}
0.090 & $* * *$ \\
\end{tabular} & \begin{tabular}{|l|l|l|}
0.077 & $* * *$ \\
\end{tabular} & \begin{tabular}{|l|l|}
0.053 & $* * *$ \\
\end{tabular} & \begin{tabular}{|c|c|}
0.071 & $* * *$ \\
\end{tabular} & \begin{tabular}{l|l|l|}
0.046 & $* *$ \\
\end{tabular} \\
\hline Years of educ. weighted by MF EA & 0.089 & *** & 0.077 & $* * *$ & 0.057 & $* * *$ & 0.066 & $* * *$ & 0.043 & ** & \begin{tabular}{l|l|l|}
0.091 & $* * *$ \\
\end{tabular} & \begin{tabular}{l|ll}
$\mathbf{0 . 0 7 7}$ & $* * *$ \\
\end{tabular} & \begin{tabular}{l|l|l|}
0.056 & $* * *$ \\
\end{tabular} & \begin{tabular}{l|l|l|}
0.065 & $* * *$ \\
\end{tabular} & \begin{tabular}{l|l|l}
0.043 & $* *$ \\
\end{tabular} \\
\hline Literacy rate $_{x}$ & 0.018 & *** & 0.016 & $* * *$ & 0.017 & $* * *$ & 0.011 & $* * *$ & 0.016 & *** & \begin{tabular}{|l|l|l|}
0.017 & $* * *$ \\
\end{tabular} & \begin{tabular}{l|l}
0.015 & $* * *$ \\
\end{tabular} & \begin{tabular}{l|l|l|}
0.016 & $* * *$ \\
\end{tabular} & \begin{tabular}{l|l|l|}
0.010 & $* * *$ \\
\end{tabular} & \begin{tabular}{l|l}
0.016 & $* * *$ \\
\end{tabular} \\
\hline Literacy rate weighted by $M F E A_{x}$ & 0.018 & *** & 0.016 & $* * *$ & 0.018 & $* * *$ & 0.010 & $* * *$ & 0.017 & *** & \begin{tabular}{|l|l|l|}
0.018 & $* * *$ \\
\end{tabular} & \begin{tabular}{l|l|l}
0.015 & $* * *$ \\
\end{tabular} & \begin{tabular}{|l|l|}
0.017 & $* * *$ \\
\end{tabular} & \begin{tabular}{l|l|}
0.009 & $* * *$ \\
\end{tabular} & \begin{tabular}{l|l}
0.016 & $* * *$ \\
\end{tabular} \\
\hline EA rate for 10-14 year olds $x_{x}$ & \begin{tabular}{|l|}
-0.019 \\
\end{tabular} & *** & -0.024 & $* * *$ & -0.034 & $* * *$ & 0.000 & & -0.025 & *** & \begin{tabular}{|l|l|}
-0.018 & $* * *$ \\
\end{tabular} & \begin{tabular}{|l|l|}
-0.023 & $* * *$ \\
\end{tabular} & \begin{tabular}{|l|l|}
-0.032 & $* * *$ \\
\end{tabular} & 0.000 & \begin{tabular}{|l|l|l|}
-0.025 & $* * *$ \\
\end{tabular} \\
\hline 2nd educ. non-enrollment rate ${ }_{x}$ & \begin{tabular}{|l|}
-0.011 \\
\end{tabular} & *** & -0.013 & $* * *$ & $\mid-0.012$ & $* * *$ & \begin{tabular}{|l|}
-0.013 \\
\end{tabular} & $* * *$ & -0.010 & $* * *$ & \begin{tabular}{|l|l|}
-0.011 & $* * *$ \\
\end{tabular} & \begin{tabular}{|l|l|}
-0.013 & $* * *$ \\
\end{tabular} & \begin{tabular}{|l|l|}
-0.012 & $* * *$ \\
\end{tabular} & \begin{tabular}{|l|l|}
-0.013 & $* * *$ \\
\end{tabular} & \begin{tabular}{|l|l|}
-0.010 & $* * *$ \\
\end{tabular} \\
\hline $\begin{array}{l}\text { Authors' industry classificati } \\
\text { regional dummy variables }\end{array}$ & \multicolumn{10}{|c|}{ Females only } & \multicolumn{5}{|c|}{ Males only } \\
\hline Years of educ. ${ }_{x}$ & 0.093 & $* * *$ & 0.072 & $* * *$ & 0.038 & $* *$ & 0.089 & $* * *$ & 0.040 & ** & \begin{tabular}{|l|l|}
0.080 & $* * *$ \\
\end{tabular} & $\begin{array}{l}0.072 \\
* * * *\end{array}$ & \begin{tabular}{l|l|l|}
0.061 & $* * *$ \\
\end{tabular} & \begin{tabular}{l|l|l|l}
0.042 & $* * *$ \\
\end{tabular} & \begin{tabular}{l|l|l}
0.038 & $* *$ \\
\end{tabular} \\
\hline Literacy rate $_{x}$ & 0.016 & *** & 0.014 & $* * *$ & 0.014 & $* * *$ & 0.011 & $* * *$ & 0.014 & *** & \begin{tabular}{|l|l|l|}
0.018 & $* * *$ \\
\end{tabular} & \begin{tabular}{l|l|l}
0.015 & $* * *$ \\
\end{tabular} & \begin{tabular}{l|l|}
0.017 & $* * *$ \\
\end{tabular} & \begin{tabular}{l|l|l|}
0.008 & $* * *$ \\
\end{tabular} & \begin{tabular}{l|l|l}
0.015 & $* * *$ \\
\end{tabular} \\
\hline EA rate for 10-14 year olds $x_{x}$ & \begin{tabular}{|l|}
-0.014 \\
\end{tabular} & $* * *$ & -0.017 & $* * *$ & -0.029 & $* * *$ & 0.003 & & -0.015 & $* * *$ & \begin{tabular}{|l|l|}
-0.018 & $* * *$ \\
\end{tabular} & \begin{tabular}{|l|l|l|}
-0.023 & $* * *$ \\
\end{tabular} & \begin{tabular}{|l|l|}
-0.032 & $* * *$ \\
\end{tabular} & -0.001 & \begin{tabular}{|l|l|l|}
-0.024 & $* * * *$ \\
\end{tabular} \\
\hline 2nd educ. non-enrollment rate ${ }_{x}$ & \begin{tabular}{|l|}
-0.009 \\
\end{tabular} & *** & \begin{tabular}{|l|}
-0.011 \\
\end{tabular} & $* * *$ & $\mid-0.010$ & $* * *$ & \begin{tabular}{|l|}
-0.012 \\
\end{tabular} & $* * *$ & \begin{tabular}{|l|}
-0.007 \\
\end{tabular} & *** & \begin{tabular}{|l|l|}
-0.012 & $* * *$ \\
\end{tabular} & \begin{tabular}{|l|l|l|}
-0.015 & $* * *$ \\
\end{tabular} & \begin{tabular}{|l|l|}
-0.013 & $* * *$ \\
\end{tabular} & \begin{tabular}{|l|l|}
-0.013 & $* * *$ \\
\end{tabular} & \begin{tabular}{|l|l|}
-0.013 & $* * *$ \\
\end{tabular} \\
\hline
\end{tabular}

Authors' industry classification, w/ regional dummy variables

EA rate for $10-14$ year olds $x_{x}(1950)$

EA rate for 10-14 year olds ${ }_{x}(1960)$

EA rate for 10-14 year olds ${ }_{x}(1970)$

EA rate for 10-14 year olds $x(1980)$

EA rate for 10-14 year olds $s_{x}(1990)$

EA rate for 10-14 year olds ${ }_{x}$ (1995)

\begin{tabular}{|c|c|c|c|c|c|c|c|c|c|}
\hline \\
\hline 0.017 & F** & -0.019 & $* * *$ & -0.014 & *** & -0.008 & **** & -0.016 & *** \\
\hline 0.018 & *** & $\mid-0.021$ & |*** & \begin{tabular}{|c|c|}
-0.018 \\
\end{tabular} & $* * *$ & -0.009 & *** & -0.019 & *** \\
\hline 0.018 & *** & $\mid-0.022$ & $* * *$ & -0.021 & *** & -0.007 & *** & -0.021 & $* * *$ \\
\hline 0.014 & *** & \begin{tabular}{|l|l|}
-0.018 \\
\end{tabular} & *** & -0.020 & *** & -0.001 & & -0.018 & $* * *$ \\
\hline-0.016 & *** & -0.021 & $* * *$ & \begin{tabular}{|c|c|}
-026 \\
\end{tabular} & *** & 0.000 & & -0.023 & $* * *$ \\
\hline-0.018 & $* * *$ & $\mid-0.023$ & $* * *$ & -0.033 & $* * *$ & 0.000 & & -0.023 & $* *$ \\
\hline
\end{tabular}

Note: *,** and $* * *$ indicate two-tailed significance at 10,5 and 1 percent levels, respectively.

Light shading indicates that less child labour or more education is associated with significantly higher exports (10 percent level or higher),

while dark shading indicates that more child labour or less education is associated with significantly lower exports. 
Table 9: Trade model results with respect to dropping one region at a time from the sample

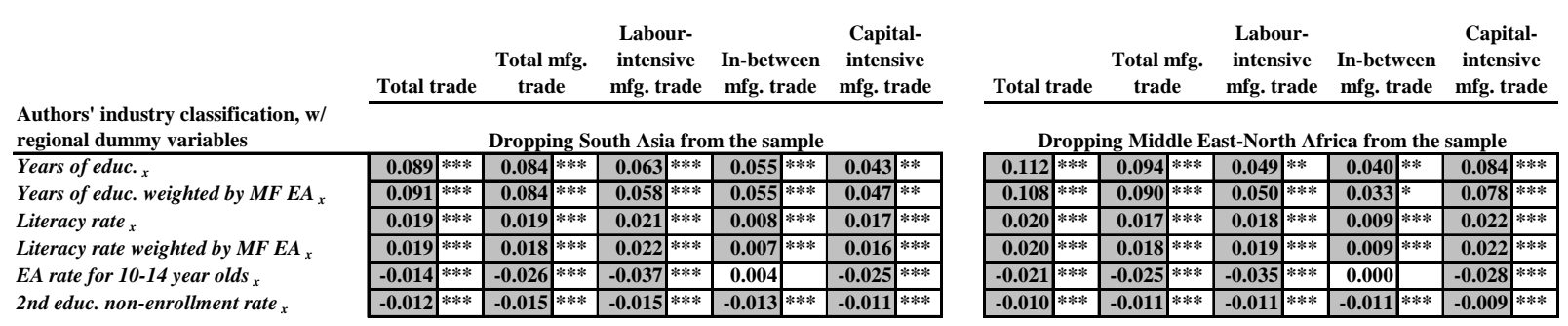

Authors' industry classification, w/ regional dummy variables Years of educ. $x$

Years of educ. weighted by MF EA Literacy rate ${ }_{x}$

Literacy rate weighted by $M F E A_{x}$

EA rate for 10-14 year olds $x_{x}$

2nd educ. non-enrollment rate ${ }_{x}$

Authors' industry classification, w/ regional dummy variables

Years of educ. $x$

Years of educ. weighted by MF EA Literacy rate

Literacy rate weighted by $M F \mathrm{EA}_{\text {x }}$

EA rate for 10-14 year olds ${ }_{x}$

2nd educ. non-enrollment rate ${ }_{x}$

Dropping Transition countries from the sample

\begin{tabular}{|c|c|c|c|c|c|c|c|c|c|}
\hline 0.089 & *** & 0.075 & $* * *$ & 0.053 & $* * *$ & 0.066 & $* * *$ & 0.040 & $* *$ \\
\hline 0.090 & $* * *$ & 0.075 & $* * *$ & 0.056 & $* * *$ & 0.060 & $* * *$ & 0.037 & * \\
\hline 0.017 & *** & 0.015 & $* * *$ & 0.016 & $* * *$ & 0.010 & *** & 0.015 & *** \\
\hline 0.017 & $* * *$ & 0.015 & $* * *$ & 0.017 & $* * *$ & 0.009 & $* * *$ & 0.015 & *** \\
\hline 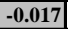 & $* * *$ & -0.023 & $* * *$ & -0.034 & $* * *$ & 0.000 & & -0.022 & $* * *$ \\
\hline$\overline{01}$ & *** & -0.01 & $* * *$ & -0.01 & $* * *$ & 0.01 & $* * *$ & -0.009 & *** \\
\hline
\end{tabular}

Dropping non-OECD East Asia-Pacific (including China) from

\begin{tabular}{|c|c|c|c|c|c|c|c|c|c|}
\hline & & & & & & & & & \\
\hline & & & & & & & & 10 & k* \\
\hline 政 & *** & & & to & & & & & **** \\
\hline 0.021 & $* * *$ & 0.016 & *** & 0.019 & *** & 0.012 & $* * *$ & 0.016 & *** \\
\hline $\begin{array}{l}-0.023 \\
\end{array}$ & $* * *$ & \begin{tabular}{|c|}
-0.026 \\
\end{tabular} & $* * *$ & \begin{tabular}{|c|}
-0.038 \\
\end{tabular} & $* * *$ & 0.000 & & \begin{tabular}{|c|}
-0.028 \\
\end{tabular} & *** \\
\hline-0.016 & $* * *$ & \begin{tabular}{|c|}
-0.017 \\
\end{tabular} & $* * *$ & \begin{tabular}{|c|}
-0.014 \\
\end{tabular} & $* * *$ & \begin{tabular}{|c|}
-0.016 \\
\end{tabular} & $* * *$ & \begin{tabular}{|l|l|}
-0.016 \\
\end{tabular} & **** \\
\hline
\end{tabular}

Dropping Sub-Saharan Africa from the sample

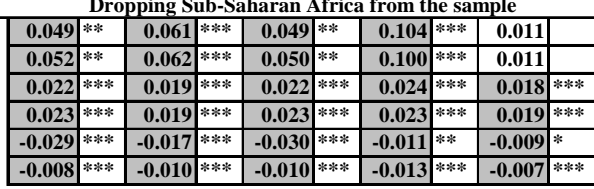

Authors' industry classification, w/ regional dummy variables

Years of educ. $x$

Years of educ. weighted by MF EA Literacy rate ${ }_{x}$

Literacy rate weighted by $M F A_{x}$

EA rate for 10-14 year olds $x_{x}$

2nd educ. non-enrollment rate $x_{x}$

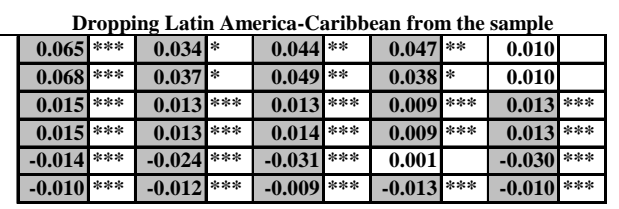

Authors' industry classification, w/

regional dummy variables

Years of educ. $x$

Years of educ. weighted by MF EA

Literacy rate

Literacy rate weighted by $M F \mathrm{EA}_{x}$

EA rate for 10-14 year olds

2nd educ. non-enrollment rate
Dropping China from the sample

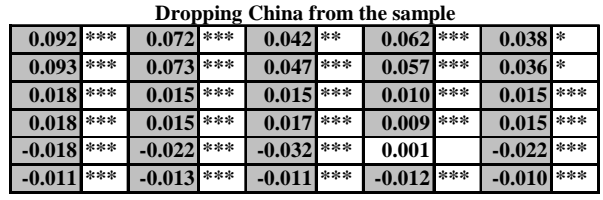

Dropping OECD from the sample (and dropping dummy

variable for Latin America-Caribbean from model)

\begin{tabular}{|c|c|c|c|c|c|c|c|c|c|}
\hline \begin{tabular}{|c|}
0.036 \\
\end{tabular} & & 0.026 & & 0.073 & $* * *$ & 0.055 & ** & -0.071 & ** \\
\hline 0.041 & & 0.028 & & 0.082 & $* * *$ & 0.053 & ** & -0.073 & ** \\
\hline $\begin{array}{l}0.015 \\
\end{array}$ & *** & 0.011 & *** & 0.010 & $* * *$ & 0.009 & $* * *$ & 0.008 & *** \\
\hline 0 & $* * *$ & 0.011 & *** & 0.011 & $* * *$ & 0.009 & $* * *$ & 0.008 & *** \\
\hline-0.012 & $* * *$ & -0.017 & *** & -0.027 & $* * *$ & 0.000 & & -0.011 & *** \\
\hline-0.008 & *** & -0.011 & क** & -0.009 & $* * *$ & -0.012 & $* * *$ & -0.005 & ** \\
\hline
\end{tabular}

Dropping OECD as exporter from the sample (and dropping dummy variable for Latin America-Caribbean from model)

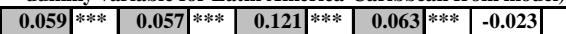

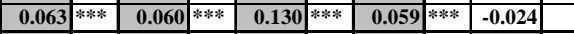

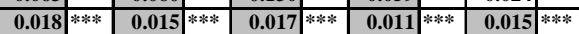

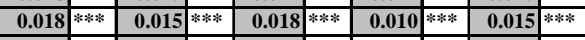

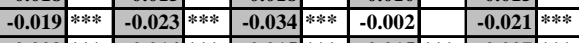

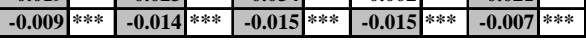

Note: *, ** and *** indicate two-tailed significance at 10,5 and 1 percent levels, respectively.

Light shading indicates that less child labour or more education is associated with significantly higher exports (10 percent level or higher),

while dark shading indicates that more child labour or less education is associated with significantly lower exports. 
Figure 1: Average Years of Educational Attainment for those 15 and Older: 1960 to 1999

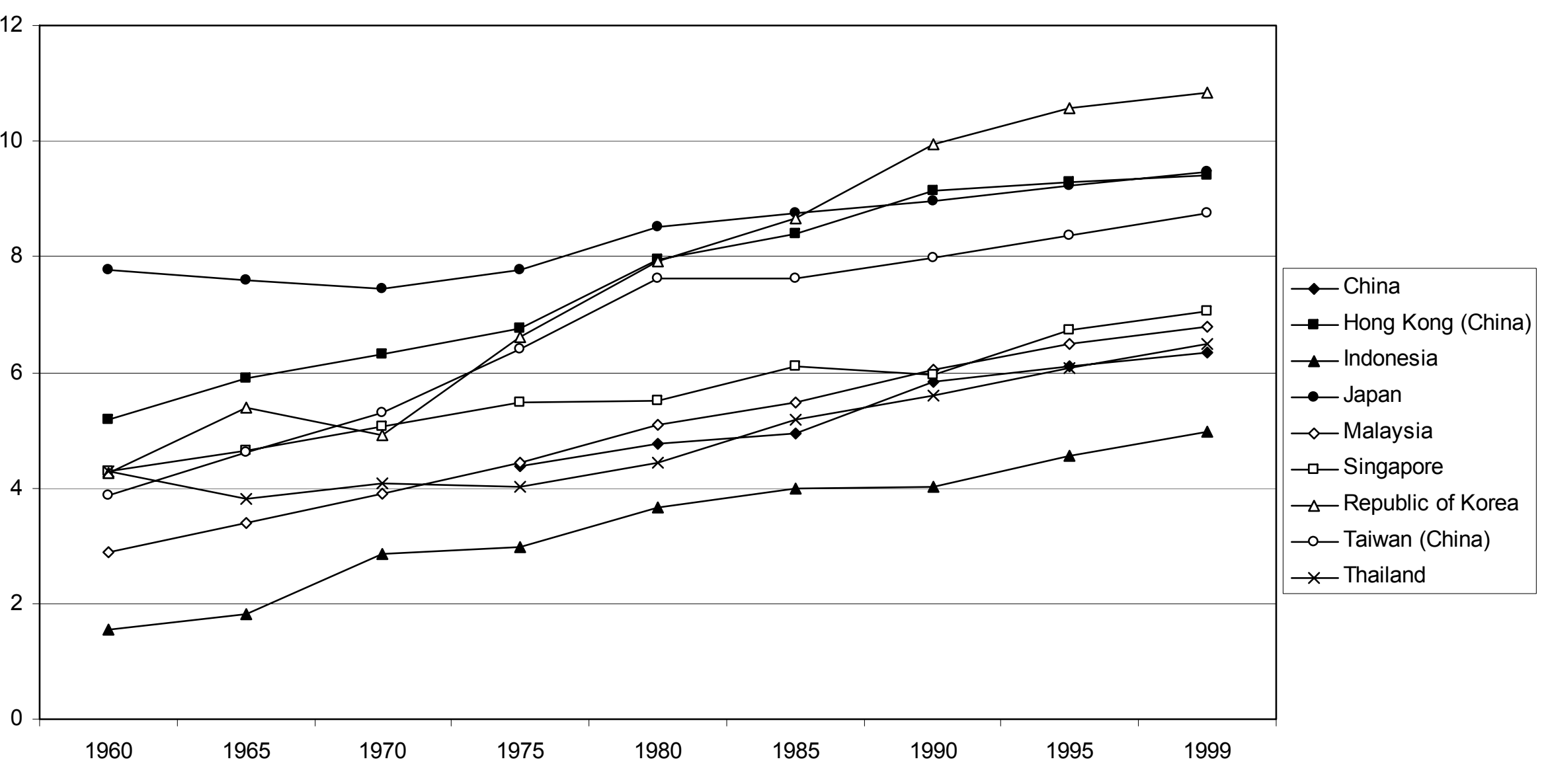


Figure 2: Coefficient estimates on regional dummy variables for six developing regions from benchmark trade model (with pre-1990s OECD the excluded region)
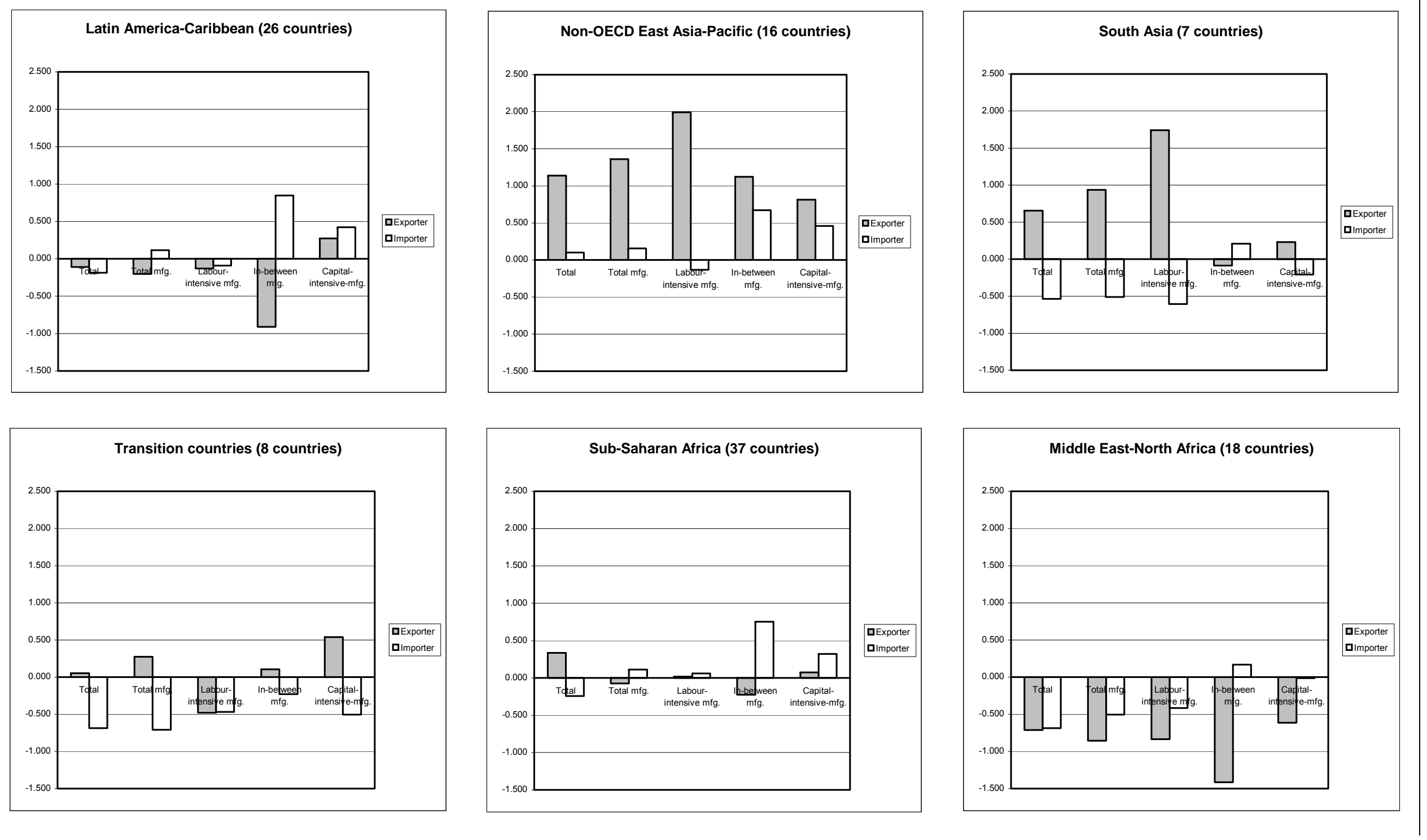


\section{Appendix: Data sources}

Trade data: Statistics Canada 2001.

Area and geographic center of countries and whether they share a common border, are landlocked or are an island: CIA website.

Manufacturing value-added, output and employment: UNIDO 2000, 2001.

Exchange rates: IMF 2002.

Regional trade agreements: WTO website.

Average years of educational attainment: World Bank website.

Literacy rates: UNDP 1998; UNESCO 1998, 1999.

Gross secondary education enrollment rates: UNESCO 1998, 1999.

Economic activity rates for 10 to 14 year olds: ILO 1996.

All other data: World Bank 2001. 


\section{Appendix: Data notes}

Eight "countries" in the Canadian World Trade Analyzer dataset are actually comprised of country or regional groups. These are as follows (Note: they do not represent ILO designations):

1. "Belgium” is comprised of Belgium and Luxembourg.

2. “Czech Republic” is comprised of the Czech Republic and Slovakia.

3. "Ethiopia” is comprised of Ethiopia and Eritrea.

4. "Guinea-Bissau” is comprised of Guinea-Bissau, Cape Verde and Sao Tome and Principe.

5. “Indonesia” is comprised of Indonesia, East Timor and Macau (China).

6. "Russian Federation" is comprised of the Russian Federation, Armenia, Azerbaijan, Belarus, Estonia, Georgia, Kazakhstan, Kyrgyzstan, Latvia, Lithuania, Moldova, Tajikistan, Turkmenistan, Ukraine and Uzbekistan.

7. "South Africa” is comprised of South Africa, Botswana, Lesotho, Namibia and Swaziland.

8. "Yugoslavia” is comprised of Yugoslavia, Bosnia and Herzegovina, Croatia, Macedonia and Slovenia.

Thus our full sample is actually made up of 162 countries or regions, for which there are discrete data for 135. (No independent variables were constructed for East Timor and Sao Tome and Principe, so data on these only figure into the left-hand side of the trade model equations and are not counted in the 162). Certain independent variables could not be constructed additively and so were constructed in the following manner. The common border dummy equals 1 if a country has a common border with any country or region in the eight groups and 0 otherwise. The regional trade agreement dummy equals 1 if a country is in a regional trade agreement with any country or region in the eight groups and 0 otherwise. The landlocked dummy equals 1 if the entire country or region group is landlocked and 0 otherwise. The island dummy equals 1 if the entire country or region group is an island and 0 otherwise. The distance between a country and the above country or region groups is taken as the distance from the geographic center of the largest country in its group. The bilateral exchange rate between a country and the above country or regional groups is taken that with the largest country in its group. (Whether measured by GDP (in current US dollars), population or land area, the largest country or region in its group is in all eight cases the country is that in quotation marks above.) Indicators of child labour and education are constructed as weighted averages, using a country or region's total economically active population as of 1995 as the weight.

In addition, GDP data were missing for some countries in the above groups for some years. Since these were constructed additively for period averages, missing values were estimated with a linear time trend for Bosnia, Macedonia and Turkmenistan for GDP in 1993 (in current US dollars) and for Georgia and Tajikistan for 1993 and 1994 (in current US dollars and PPP). Data for GDP in PPP for Tajikistan were taken from World Development Indicators for 2000, as they were not available in the 2001 edition. 
Appendix Table 1: Correspondence between ISIC Rev. 2 and SITC Rev. 2 for manufacturing industries

ISIC Rev. 2 by author's industry classification Labour-intensive manufacturing industries

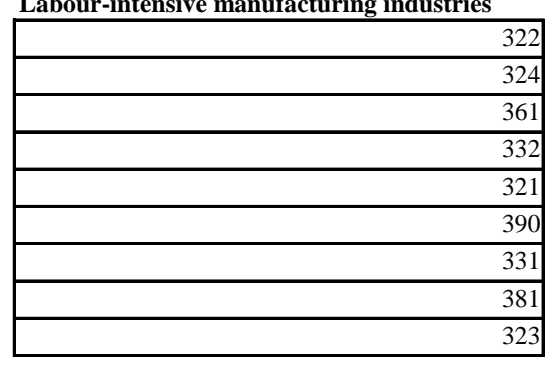

SITC Rev. 2 (as per World Trade Analyzer database)

Labour-intensive manufacturing industries

$842,843,844$

\begin{tabular}{l}
$8 \underline{85}, \underline{843,04}$ \\
\hline $666,8122,812 \mathrm{X}$
\end{tabular}

666, 8122, 812X

82

269, 26X, 65, 845, 846, 847, 8481, 8482, 8484, 848X, 84X

8941, 8942, 8947, 894X, 895, 896, 897, 898, 899

$248,24 \mathrm{X}, 63$

691, 692, 693, 694, 695, 696, 697, 6991, 6992, 6993, 6994, 6996, 6998, 6999, 699X, 69X, 8121

$61, \underline{\mathbf{3}}, 8483$

In-between manufacturing industries

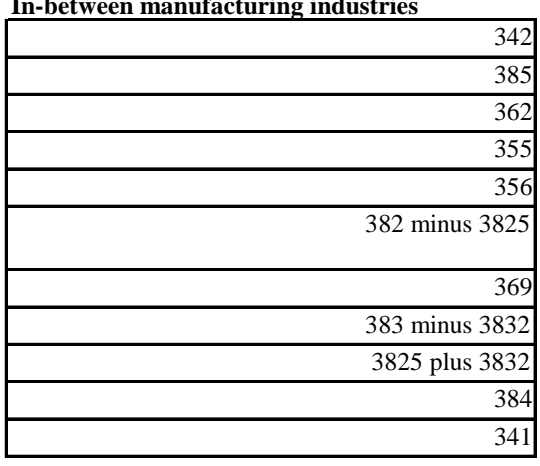

Capital-intensive manufacturing industries

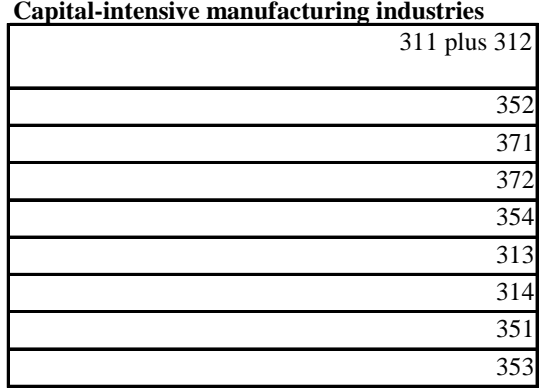

In-between manufacturing industries 892

$87,881,884,885,88 X$

$\underline{664}, \underline{65}$

233,62

893

711, 712, 7138, 7139, 713X, 714, 718, 71X, 72, 736, 7371, 7372, 737X, 73X, 7411, 7412, 7414, 7415, 7416, 741X, 742, 743,

$744,745,749,74 \mathrm{X}, 7751,7752,7753,7758,775 \mathrm{X}, 7784, \mathbf{8 9 4 6}, 95$

$661,662,663,66 \mathrm{X}$

716, 7373, 7413,771,772, 773,774,7754,7757,776,7781,7782, 7783,7788,778X, 77X, 8124

75,76

$7131,7132,7133,78,79$

25,64

\section{Capital-intensive manufacturing industries}

1, 0224, 023, 024, 0342, 0344, 035, 037, 03X, 0422, 046, 047, 048, 04X, 0546, 056, 0583, 0585, 0586, 0589, 058X, 05X, (IS1C, 0612, 0615, 0619, 062, 0722, 0723, 073, 091, 098, 09X, 4 (ISIC 311); 0712, 0812, 0813, 0814, 0819, 081X (ISIC 312) $5332,5334,5335,533 \mathrm{X}, 54,5513,551 \mathrm{X}, 553,554,55 \mathrm{X}, 57,882,883$

68

$323,32 X, 3352,3353$

\begin{tabular}{ll}
11 \\
\hline 122 \\
\hline
\end{tabular}

$266,267,274,51,52,531,532,5331,53 X, 5514,56,58,59,5 X$

334, 3351, 3354, 3359, 335X

Note: "X" is used on the World Trade Analyzer database to indicate "not elsewhere classified."

When an SITC industry contains both manufactures and non-manufactures, we exclude it from manufacturing and the above table.

Regarding SITC, underlined and bolded figures represent, respectively, Krause's and Busse's unskilled labour intensive industry classifications+A13. 


\section{Policy Integration Department Working Papers}

No. 1 ILO activities on the social dimension of globalization: Synthesis report

No. 2 Measuring decent work with statistical indicators,

Richard Anker, Igor Chernyshev, Philippe Egger, Farhad Mehran and Joseph Ritter

No. 3 Globalization and decent work: Options for Panama Philippe Egger

No. 4 Globalización y trabajo decente: Opciones para Panamá, Philippe Egger

No. 5 Indicators of social dialogue: Concepts and measurements, Lane Kenworthy and Bernhard Kittel

No. 6 Assessing the impact of the attacks of 11 September 2001 on women's employment in the United States, Gertrude Schaffner Goldberg and Helen Lachs Ginsburg

No. 7 Decent work and the informal economy in Central America, Juan Diego Trejos Solórzano and Miguel Del Cid

No. 8 Poverty initiatives in the ILO: A review of past and present approaches, Pat Holden and Dagmar Walter

No. 9 Whither the International Standard Classification of Occupations (ISCO-88)?, Debbie Budlender

No. 10 Improving occupational classifications as tools for describing labour markets: A summary of recent national experiences, Debbie Budlender

No. 11 Recent developments in China's labour economy, Thomas G. Rawski

No. 12 The Impact of economic liberalization on employment and wages in India, Sonia Bhalotra

No. 13 The impact of trade liberalization upon inequality in developing countries, Donald J. Robbins

No. 14 The impact of liberalization and globalization on income inequality in developing and transitional economies, Giovanni Andrea Cornia

No. 15 The impact of technology transfer on employment and income distribution in developing countries: A survey of theoretical models and empirical studies, Mariacristina Piva 


\section{Policy Integration Department Working Papers prepared for the World Commission on the Social Dimension of Globalization}

No. 16 International finance: Meeting the needs of people in developing countries, José Guilherme Almeida dos Reis

No. 17 The gender dimensions of globalization of production, Stephanie Barrientos, Naila Kabeer and Naomi Hossain

No. 18 Social exclusion in the context of globalization, Jan Breman

No. 19 Gender and globalization: A macroeconomic perspective, Çağatay Nilüfer and Ertük Korkurt

No. 20 Globalization, social exclusion, and work: with special reference to informal employment and gender, Marilyn Carr and Martha Chen

No. 21 Resources for social development, Antony Clunies Ross

No. 22 Does the new international trade regime leave room for industrialization policies in the middle-income countries?, Alisa DiCaprio and Alice Amsden

No. 23 Social dimension of globalization in Latin America: Lessons from Bolivia and Chile, Alvaro García Hurtado

No. 24 The social dimension of globalization: a review of the literature, Bernhard Gunter and Rolph van der Hoeven

No. 25 The social dimension of global production systems, Susan Hayter

No. 26 Reforming global economic and social governance: a critical review of recent programmatic thinking, Jeremy Heimans

No. 27 Corporate social responsibility: an issues paper, Michael Hopkins

No. 28 Upgrading in global value chains, John Humphrey

No. 29 Implications of globalization and economic restructuring for skills development in Sub-Saharan Africa, Richard K. Johanson

No. 30 The outcome and impact of the main international commissions on development issues, Frédéric Lapeyre

No. 31 Globalization and structural adjustment as a development tool, Frédéric Lapeyre

No. 32 Globalization and perceptions of social inequality, Malte Luebker

No. 33 The changing structure of international trade linked to global production systems: what are the policy implications?, William Milberg

No. 34 Corporate social responsibility: an overview of principles and practice, Jill Murray

No. 35 Inclusive development strategy in an era of globalization, Ignacy Sachs

No. 36 Social consequences of the globalization of the media and communication sector: some strategic considerations, Seán Ó. Siochrú

No. 37 Globalization, history and international migration: a view from Latin America, Andrés Solimano

No. 38 Towards a different kind of globalization, or how the anti-globalists view the world, Gijsbert van Liemt 


\section{Policy Integration Department Working Papers}

No. 39 How do trade union rights affect trade competitiveness?

David Kucera and Ritash Sarna

No. 40 Statistics on the employment situation of people with disabilities: A compendium of national methodologies

ILO Bureau of Statistics in collaboration with the In Focus Programme on Skills, Knowledge and Employability

No. 41 Employment in the informal economy in the Republic of Moldova

ILO Bureau of Statistics in collaboration with the Department for Statistics and Sociology of the Republic of Moldova

No. 42 Decent work in a least developed country: A critical assessment of the Ethiopia PRSP, Graeme J. Buckley

No. 43 Unemployment and Labour Market Institutions: The Failure of the Empirical Case for Deregulation,

Dean Baker, Andrew Glyn, David Howell and John Schmitt

No. 44 Women's access to occupations with authority, influence and decision-making power: Women as legislators, senior officials and managers around the world, Richard Anker.

No. 45 The world of work in the context of economic integration and trade liberalization, Daniel Martínez

No. 46 Poverty reduction in Pakistan: The strategic impact of macro and employment policies, Moazam Mahmood

No. 47 Trends in Work Stoppages: A Global Perspective, L. J. Perry and Patrick J. Wilson

No. 48 Generating decent work for poverty reduction in Cambodia: The voice of workers, employers and the Government; Moazam Mahmood

No. 49 The Social Dimension of Regional Integration in ECOWAS René Robert

No. 50 Measuring trade union rights: A country-level indicator constructed from coding violations recorder in textual sources David Kucera

No. 51 Patterns of decent work attributes in European Union Joseph Ritter

No 52 Child Labour, Education and Export Performance David Kucera and Ritash Sarna 
